\title{
Synoptic revision of the Silurian fauna from the Pentland Hills, Scotland described by Lamont (1978)
}

\author{
Yves Candela and William R.B. Crighton
}

\begin{abstract}
Archibald Lamont (1907-1985) sampled the North Esk Inlier Silurian fauna for almost 30 years. He had amassed a substantial fauna that has been, in part, bequeathed to the National Museums Scotland after his death. Unfortunately, the descriptions of the faunas in his last opus were careless and the illustrations were uninformative. Nonetheless, these highlight the singularity and diversity of the Silurian invertebrate faunas in the North Esk Inlier. The taxa erected by Lamont are reviewed, discussed and properly illustrated, at least for those specimens that have been found in the collections of National Museums Scotland. An attempt has also been made to give more precision on the localities and horizons, based on the information in Lamont's article and on the various labels accompanying the specimens in storage.
\end{abstract}

Yves Candela. Department of Natural Sciences, National Museums Scotland, Chambers Street, Edinburgh EH1 1JF, Scotland. y.candela@nms.ac.uk

William R.B. Crighton. National Museums Collection Centre, 242 West Granton Road, Edinburgh EH5 1JA, Scotland. B.Crighton@nms.ac.uk

Keywords: museum collections; North Esk Inlier; palaeontology; Scotland; systematics

Submission: 9 March 2018 Acceptance: 17 March 2019

\section{INTRODUCTION}

Despite the many criticisms printed after its publication, Lamont's (1978) paper remains an interesting document of the diversity of faunas in the North Esk Inlier (NEI) with an emphasis on the localities lying west and north-west of the North
Esk Reservoir. It also illustrates the peculiarity of the Silurian fauna, with many taxa unique to the North Esk Inlier (NEI) (e.g., Mirmor andreae Lamont, p. 277, plate 32 , figure 1).

Lamont worked at the University of Edinburgh as a Carnegie Research Fellow and University

Candela, Yves and Crighton, William R.B. 2019. Synoptic revision of the Silurian fauna from the Pentland Hills, Scotland described by Lamont (1978). Palaeontologia Electronica 22.2.19A 1-45. https://doi.org/10.26879/868

palaeo-electronica.org/content/2019/2472-scottish-silurian-fauna

Copyright: May 2019 Palaeontological Association.

This is an open access article distributed under the terms of Attribution-NonCommercial-ShareAlike 4.0 International (CC BY-NC-SA 4.0 ), which permits users to copy and redistribute the material in any medium or format, provided it is not used for commercial purposes and the original author and source are credited, with indications if any changes are made.

creativecommons.org/licenses/by-nc-sa/4.0/ 
Research Fellow from 1945 to 1951. Owing to a deteriorating health (asthma) and also having quarrelled with the then Professor (Clarkson, 2007), Lamont retired and remained in his cottage in Carlops, becoming increasingly more isolated from the palaeontological community. He started lacking the discipline of referees for his published work and ran into problems with editors. From 1965 he produced, edited and was largely the sole contributor to the Scottish Journal of Science. In consequence, his later scientific papers have lost the significance of his earlier publications.

The formal requirements of the ICZN regarding the validity of a name (see Article 11) are followed by Lamont in his 1978 article: e.g., name or nomenclatural act is published in the meaning of Article 8 , mandatory use of Latin alphabet, name derived from any language (or an arbitrary combination of letters providing this is formed to be used as a word), principle of binomial nomenclature applied. However, regarding the criteria of availability for names published after 1930, Lamont failed to identify and make clear the characters that differentiated his new taxon, often not adhering to Article 13 (in particular Clause 13.1.1) of the ICZN. In any case, he failed to conform to good practice when erecting his new taxa: holotype is not clearly fixed (a general statement introduces the taxonomic paragraph: "Figured specimens of new species are to be treated as holotypes or syntypes", $p$. 246); in the majority of cases, the diagnosis is not clearly differentiated (ICZN Recommendation 13A not followed); there is a lack of clear and consistently present comparison with related or similar taxa. On some occasions, a description of the diagnostic features including a comparison with other taxa is present and can be interpreted as a differential diagnosis as described by Cifelli and KielanJaworowska (2005). However, this is these authors' interpretation of Article 13 of the ICZN.

As mentioned above, Lamont's paper also lacks a clear and unambiguous reference to type material; only four specimens are clearly and unambiguously referred to with a museum catalogue number. However, data on the labels accompanying each specimen and kept in storage together with the specimen at the National Museums Scotland (NMS), clearly relates each specimen to the specimen figured on Lamont's plates 25 to 32 because of the unequivocal labelling by Lamont.

For the reasons enumerated above, this work has since its publication been regarded with contempt or simply ignored, and many of the new taxo- nomic names are, in fact, junior synonyms or were declared invalid. Nevertheless, Lamont was, in the words of Euan Clarkson (2000), "a man of great erudition and intellectual qualities" and his earlier work was of decisive importance in the understanding of the NEI fauna and Palaeozoic palaeontology (see Lamont, 1947, 1948, 1955 and Lamont, 1935, 1941, 1949, respectively).

\section{THE COLLECTIONS}

\section{The Lamont Collection}

The collection on which Lamont based his study is a mix of collections borrowed from the NMS (formerly Royal Scottish Museum as it would have been called at the time Lamont was in possession of the specimens), such as the Henderson Collection [prefix NMS G.1876.42] and the Hardie Collection [prefix NMS G.1897.32], as well as specimens collected by R.P. Tripp and Rennie Wilson, along with his own collection (subsequently registered with prefix NMS G.1979.45 and NMS G.1979.77). He had accumulated an extensive collection of specimens from the North Esk Inlier, as he lived for the last 30 years of his life in a small cottage in Carlops, on the doorstep of the North Esk Inlier. Unfortunately, some specimens went missing when, after Lamont's death, part of his personal collection (from the east of Scotland and the Pentland Hills) was transferred to the National Museums' collection or others were registered a second time from one of the historic collections listed above when the original information was lost or mislaid. The rest of Lamont's personal collection was divided between the Hunterian Museum, Glasgow University (material from the west of Scotland and the Girvan area), the National Museum of Ireland, Dublin (material from Ireland) and the National Museum of Wales, Cardiff (material from Wales and the Welsh Borderland) as directed by the executors of Lamont's estate.

The information regarding the localities is here reproduced from either the information available in Lamont (1978), or available from handwritten notes attached or associated with the specimens and preserved in the NMS palaeobiology collection. An exact locality is difficult to pinpoint as it is often described with a single word (e.g., "Deerhope"), but sometimes the description of the locality makes its location unquestionable (e.g., locality R82 described in the words of Lamont by "N. Esk Wether Law Linn junction"). Locality information given in the historical collections tends to be brief and, in any case, not consistently recorded. For 


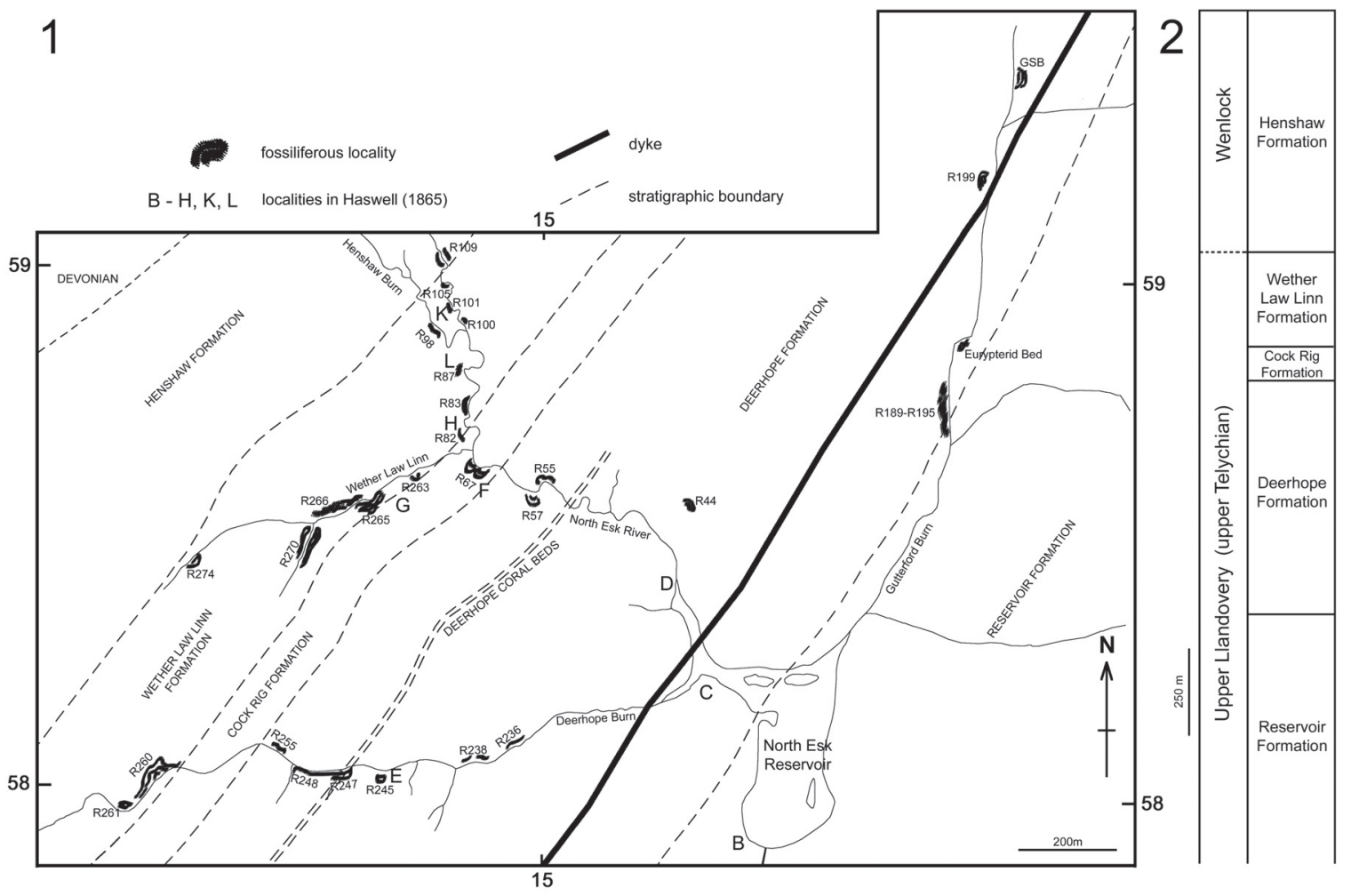

FIGURE 1. 1: Simplified geological map of the North Esk Inlier in the vicinity of the North Esk Reservoir (north-east quadrant), with indication of some of the best known fossiliferous localities (R-numbers); localities from Haswell (1865) are also indicated, noted B to H, K, L: E=R245, F=R57, G=R263 or R265, H=R82, K=R101, L=R93; Gutterford Starfish Bed: R199; GSB: Gutterford Starfish Bed as described by Peach and Horne (1899). Grid reference in margin [NT]. Adapted from Clarkson and Taylor (2007a) and Anderson et al. (2007). 2: Stratigraphy of the Silurian beds in the NEl; adapted from Clarkson and Taylor (2002) and Molyneux et al. (2008) and taking into account the revised thickness of the Deerhope Formation suggested by Anderson et al. (2007).

example, in the Henderson Collection, the locality is often given as "Deerhope", but the stratigraphic information sometimes does not match.

Haswell (1865), on his map, used the name "Deerhope" for the section of the North Esk River that runs into the north-west part of the North Esk Reservoir. Brown and Henderson (1868, page 28) picked up the mistake, but it would be interesting to know whether the collection was registered following Haswell's mistake or not. We discuss below, for each of Lamont's taxa, the locality according to the available information.

\section{The Henderson Collection}

John Henderson was a self-educated man whose geological and palaeontological interests focused on Scottish geology, and, more specifically, the area around Edinburgh. He was curator at the Phrenological Museum in Edinburgh, which opened in the mid 1820s and closed in 1886 ("door-keeper at the slightly comical Phrenological Museum in Chambers Street" (Lamont, 1948, page 533)) and was a member of the Edinburgh Geological Society. His views on geology and palaeontology were highly regarded by his contemporaries such as Thomas Davidson (1868), Charles Lapworth (1874) and Robert Etheridge, Jr. (1874) and also acknowledged posthumously (Goodchild, 1903; Peach et al., 1910). Nevertheless, he also had opponents; perhaps because he had not trained through the academic channel, his views were regarded in a condescending manner. He entered into a conflict with the Geological Survey (Archibald Geikie was the director at the time) over the age of the Silurian series in the NEI. Brown and Henderson (1868) had the "temerity of advancing views contrary to those held by the Survey authorities" (Goodchild, 1903, page 167). However, as 
Goodchild noted, their views eventually turned out to be correct and widely accepted. The Geological Survey Memoir regarded the Silurian rocks in the $\mathrm{NEI}$ as Ludlow (Howell and Geikie, 1861), whereas Murchison regarded them as of Wenlock age. Brown and Henderson (1868) regarded them as older than the Survey believed them to be; i.e., Wenlock, up to and including 'Bed F' (equivalent to the middle part of the Wether Law Linn Formation), gradually passing into the Ludlow ('Bed H'; equivalent to the upper part of the Wether Law Linn Formation). Later, Lapworth (1874) ascertained a Wenlock age for the Silurian rocks in the Pentland Hills, based on graptolites collected by John Henderson. He was right in thinking that the series were older than what was thought to be Ludlow in age, but it was not until Lamont (1947) that an upper Llandovery age for the Silurian rocks was finally demonstrated.

\section{THE NORTH ESK INLIER}

The majority of the specimens described and illustrated by Lamont were collected from the North Esk Inlier, the largest of the three Silurian inliers in the Pentland Hills. Exposure in the inlier is quite good, but it is restricted to the banks of the few burns located in the vicinity of the North Esk Reservoir (Figure 1). The sedimentary beds are highly inclined to vertical, striking in a NE-SW direction and younging to the NW (see Clarkson and Taylor, 2007a). This Silurian sequence witnessed phases of a continuous marine regression, involving the establishment of an offshore barrier system, shoreward of which lay a broad marine lagoon, represented by the Wether Law Linn Formation (see Clarkson and Taylor, 2007a). The Wether Law Linn Formation was divided into Lower, Middle and Upper members by Robertson (1989), but Molyneux et al. (2008) renamed these as Grain Heads Siltstone, Lamb Rig Siltstone and Baddinsgill Mudstone members. Nevertheless, we continue using Robertson's (1989) names in this article.

\section{TAXONOMIC INFORMATION}

Lamont's taxa are listed below following their order on the publication's plates. The taxonomy used by Lamont in his publication is retained here and on the figure captions. Revised taxonomic names are discussed in the comments for each taxon below. A summary of the revision is provided on a table in the Appendix.

\author{
Plate XXV, figures 1-3; page 246 \\ Fingala galea Lamont, 1978
}

Figure 2.1-4

NMS G.1876.42.71.1: Henderson Collection. "Deerhope, Gala-Tarannon"; locality as R260, Deerhope Burn; lower part of the Wether Law Linn Formation.

Lamont (1978) assigned his specimen to the gastropod superfamily Patellacea Rafinesque, based on the coiled protoconch, although the identification of the structure he illustrated on plate 25 , fig. 3 as protoconch seems doubtful. This feature rather looks like the external mould of a crinoid ossicle, therefore preserved as a 'ghost', near the apex of the shell, giving the impression of a 'coiled' structure.

Lamont also compared Fingala galea with the monoplacophoran taxa Vallatotheca and Pilina, but refuted the affinity based on Fingala being "more transverse and convex, with elevated, protrusive apex" (p. 246).

Lemche and Wingstrand (1959) described a dextrally coiled protoconch in the monoplacophoran Neopilina galatheae Lemche, but this was subsequently demonstrated to be wrong as such a feature has never been observed in recent Monoplacophora (Bouchet et al., 1983); the protoconch in Monoplacophora is bulbous. More material is needed, in particular internal views and more complete shells, in order to confirm the taxonomic position of the specimen.

Lamont (1978) did not describe the genus, but provided some basic comparisons with other taxa in order to justify his new genus. Article 13.1.1 of the ICZN states that to be regarded available, a name should "be accompanied by a description or definition that states in words characters that are purported to differentiate the taxon...". Lamont did not state characters that differentiated his taxon, he only proposed a relative description of some of the characters he deemed important (e.g., "more transverse..." on page 246), Therefore this cannot be regarded as satisfactory to validate the name and in consequence, the name is a nomen dubium.

The reference to ?Sinuites aff. semirugosus Reed on the label (Figure 2.4) concerns a different specimen that was originally presented with Fingala on the same display plate.

Plate XXV, figure 4; page 248

Pterotheca gath Lamont, 1978

Figure 2.5, 8, 9

NMS G.1897.32.746: collected by Mr David Hardie. 


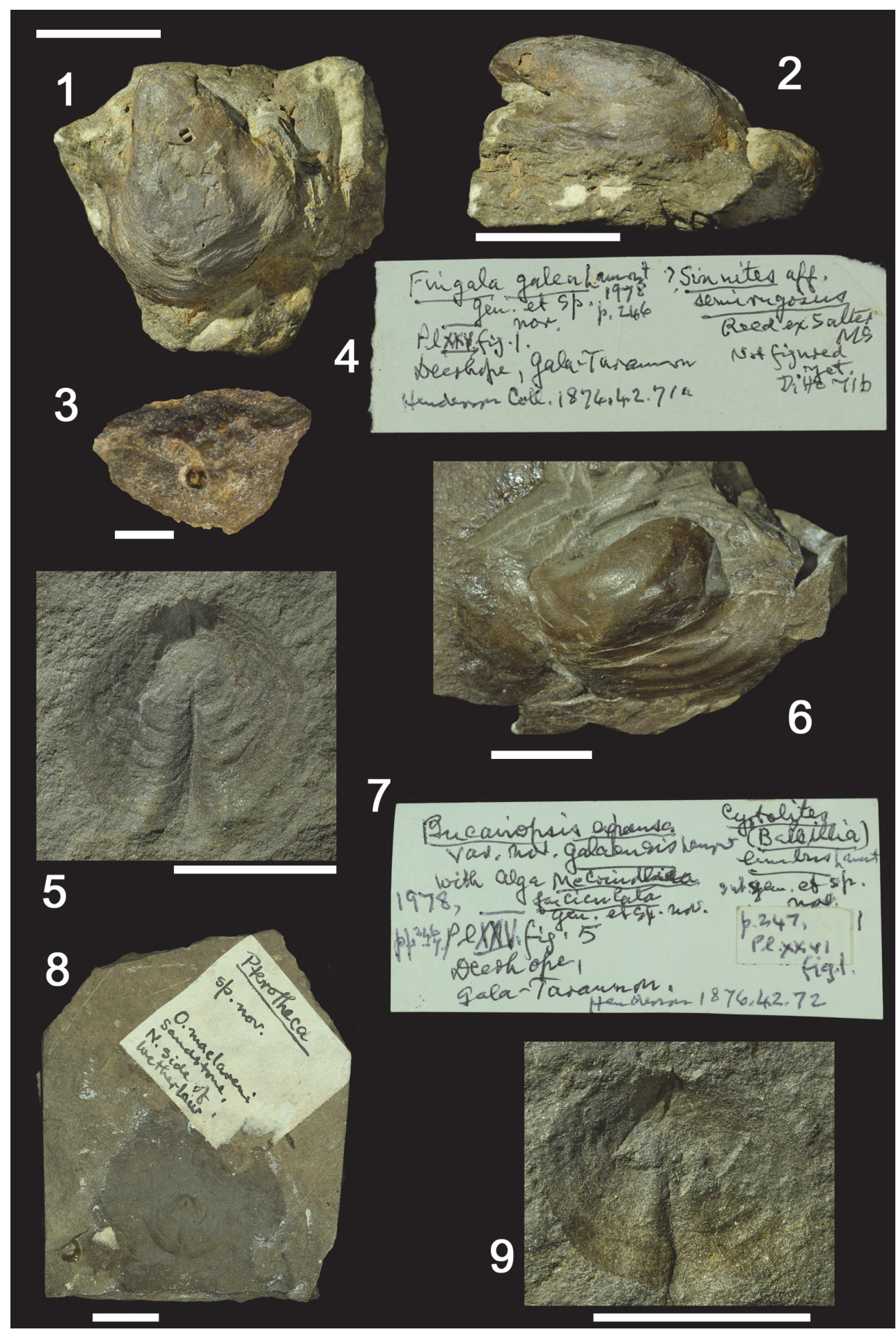

FIGURE 2. 1-4: Fingala galea Lamont, 1978, from locality R260, Deerhope Burn, lower part of the Wether Law Linn Formation; 1, 2: top and side views of specimen NMS G.1876.42.71.1 from the Henderson Collection; 3: posterior view of the shell showing in detail the 'protoconch' as shown in Lamont, pl. 25, fig. 3; 4: handwritten label associated with the specimen. 5, 8, 9: Pterotheca gath Lamont, 1978, from locality R83, Wether Law Linn Formation. 5: dorsal view of specimen NMS G.1897.32.746 from the Hardie Collection; 8, 9: view of the sample including the label written by A. Lamont and dorsal view of specimen NMS G.1995.66.1. 6, 7: Bucaniopsis expansa var.galaensis Lamont, 1978, from the Deerhope Burn; 6: adapertural view of specimen NMS G.1876.42.72.1 from the Henderson Collection; 7: handwritten label associated with the specimen (left hand side). Scale bars: $10 \mathrm{~mm}$ (figures 1, 2, 5, 8, 9); 5 $\mathrm{mm}$ (figure 6); $1 \mathrm{~mm}$ (figure 3). 
The specimen illustrated by Lamont appears to be NMS G.1897.32.746 rather than NMS G.1995.66.1 as Ebbestad (2007) recorded. The former more closely resembles the illustrated specimen in its ornament and circular shape. NMS G.1995.66.1 was collected from the "N. side of Wetherlaw", not along the banks of the Wether Law Linn, but slightly north, at locality R83.

NMS G.1897.32.746 bears "Deerhope" engraved on the matrix: another engraving reads " $245 \mathrm{PH} . \mathrm{H}$ " which means locality R245, according to the locality number by Robertson (1989). It is not clear whether both engravings are contemporary or not. Haswell (1865) showed a map of the fossiliferous localities in the vicinity of the North Esk Reservoir to illustrate his book on the geology of the Pentland Hills. On this map he marked the name Deerhope Burn on the NW branch of the North Esk River that runs into the North Esk Reservoir. A few years later Brown and Henderson (1868) picked up and corrected the error. Careful comparison of specimen NMS G.1897.32.746 with NMS G.1995.66.1 reveals that the lithology of the samples is identical and typical of the Wether Law Linn Formation.

Two species have been recorded from the NEl: $P$. aff. mullochensis from the Deerhope Formation and $P$. trimerelloides Clarkson et al., 1995, from the Wether Law Linn Formation (see Clarkson et al., 1995). These two species can be distinguished from each other in three ways: trimerelloides has a shorter and narrower platform, stronger developed rugae on the posterolateral surfaces of the shell and a broader and more pronounced sulcus where the keel is developed. These features are developed in the specimens figured here. Therefore, $P$. trimerelloides can be regarded as a junior subjective synonym of $P$. gath as suggested by Ebbestad (2007).

Specimens NMS G.1897.32.746 and NMS G.1995.66.1 are figured by Ebbestad (2007, pl. 17, figs. 1 and 2, respectively.

Plate XXV, figure 5; page 246

Bucaniopsis expansa var. galaensis Lamont, 1978 Figure 2.6-7

NMS G.1876.42.72.1: Henderson Collection. "Deerhope, Gala-Tarannon"; Deerhope Burn.

Lamont's new taxon lacks a diagnosis and/or description and comparison with other taxa that would validate the new taxon name; therefore, the name galaensis can be regarded as nomen nudum (fails to conform to Articles 10 and 13 of the ICZN).

The genus name Bucaniopsis is regarded as synonym of Bucanopsis (see database: molluscadatabase.eu).
[On figure 5: McCrindlea fasciculata Lamont, 1978 (alga)]

This new generic name should be regarded as nomen nudum as there is no diagnosis/description of the proposed new genus and no comparison with other taxa (fails to conform to Articles 10 and 13 of the ICZN).

Plate XXV, figures 6, 7; page 247

Cymbularia johannis Lamont, 1978

This specimen was noted as NMS G.1876.42.70.1; but this is an error and not the figured specimen, which seems to be missing.

Lamont (1978) failed to provide a description and comparisons with other taxa; therefore, the species name is regarded as nomen nudum as it fails to conform to Articles 10 and 13 of the ICZN.

The genus was regarded as a subgenus of Bellerophon (see Sowerby in Murchison, 1839) and described within the superfamily Bellerophontacea by Lamont (1978) [now Bellerophontoidea, see also Wagner, 2001; Horný, 2002].

Plate XXV, figure 8; page 247

Bellerophon kentigerni Lamont, 1978

Figure 3.1-2

NMS G.1982.20.5; Henderson Collection. "Deerhope (or ?Wetherlaw)": locality as Deerhope Burn or Wether Law Linn (see label by Lamont). Lamont noted this specimen as from the Henderson collection, but no note of the registration number was recorded.

The species name can be considered available on the basis that it fulfils Article 13 of the ICZN as Lamont listed in his 'Remarks' for the species the characters that described the taxon. It would have been clearer for the reader if Lamont had stated that this should be regarded as a diagnosis.

Plate XXV, figure 9; page 252

Platyceras (Acroculia?) antiquata Salter, 1861

Figure 3.3-5

NMS G.1876.42.69: Henderson Collection; locality as Deerhope Burn, possibly R260, Wether Law Linn Formation.

Lamont regarded this specimen as a juvenile of the species, which he illustrated as an adult form on plate $\mathrm{XXVI}$, figure 10 (see remarks below).

Plate XXV, figure 10; page 253

Hormotoma balmerino Lamont, 1978

Specimen is not traced. Locality as Henshaw Burn; "found with disjointed Cystids at the Henshaw Burn". 

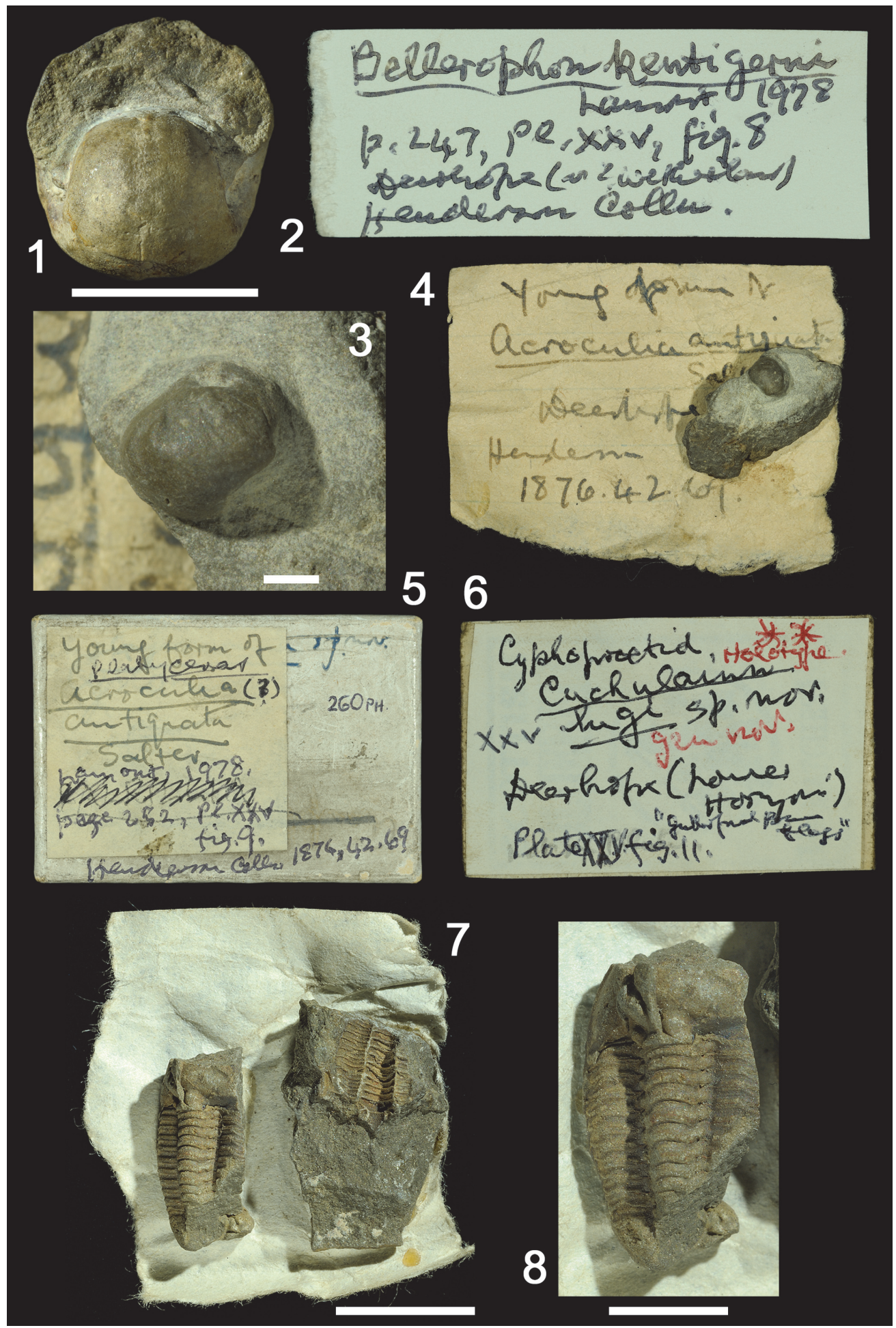

FIGURE 3. 1, 2: Bellerophon kentigerni Lamont, 1978, from the North Esk Inlier (exact locality unknown, Deerhope Burn or Wether Law Linn); 1: apertural view of specimen NMS G.1982.20.5 from the Lamont Collection; 2: handwritten label associated with the specimen. 3-5: Platyceras (Acroculia?) antiquata Salter, 1861, from locality R260 of the Deerhope Burn; 3, 4: side view of a single whorl of specimen NMS G.1876.42.69 from the Henderson Collection; note that the specimen is glued onto its label (4); 5: handwritten label associated with the specimen. 6-8: Cuchulain lugi Lamont, 1978, from the Deerhope Burn (?), Deerhope Formation; 6: handwritten label associated with the specimen; 7, 8: view of part and counterpart, and close-up of the internal mould of specimen NMS G.1979.77.34. Scale bars: 10 $\mathrm{mm}$ (figures 1, 7); $5 \mathrm{~mm}$ (figure 8); $1 \mathrm{~mm}$ (figure 3). 
Paul and Donovan (2011) identified the Cystid beds of Lamont as "the uppermost Cock Rig Formation, exposed at locality R260 of Clarkson and Taylor (2007a)". However, this locality is exposed along the Deerhope Burn, not the Henshaw Burn.

The description and comparison with other taxa are very brief, but sufficient to validate the name according to Article 13 of the ICZN. However, the absence of holotype implies that the name is regarded here as nomen dubium.

\section{Plate XXV, figure 11; page 268 Cuchulain lugi Lamont, 1978 \\ Figure 3.6-8}

NMS G.1979.77.34: Lamont collection; Deerhope Burn; horizon recorded as "Gutterford Burn flags" which corresponds to the Deerhope Formation (possibly localities R245-R248).

Lamont (1978) provided a description and comparison with other taxa that fulfil Articles 10 and 13 of the ICZN. Therefore, Lamont's (1978) species can be regarded as valid (see also Jell and Adrain, 2002).

In particular Lamont compared his taxon with Cyphoproetus and ranked Cuchulain within the same family. However, although slightly deformed and damaged, the cephalon of Cuchulain is different. For example, Cuchulain possesses a glabellar lobe L1 large and bulbous and resembles that found in calymenid trilobites. It can be estimated that L1 is about a quarter as wide as the glabella, and appears oval in outline. These features are also shared by Calymene frontosa Lindström, which is also present in the NEI but in the Wether Law Linn Formation and rare in the Deerhope Coral Beds (R247) (Clarkson and Taylor, 2007b). Lamont did not compare, unfortunately, this specimen with Calymene carlops described on page 274 , subsequently reassigned to Calymene frontosa by Clarkson and Howells (1981); see below for discussion. The pygidium is damaged and cannot be compared with Calymene frontosa.

Until more material from the same horizon is collected, the binomial is regarded as valid.

Plate XXVI, figure 1; page 247

Cyrtolites (Balsillia) limbus Lamont, 1978

Figure 4.1-5

NMS G.1876.42.72.2: Henderson Collection. Deerhope Burn.

In the Worldwide Mollusc Species DataBase (WMSDB), the binomial Balsillia limba (Lamont, 1978) is regarded as valid (within Archaeogastropoda). A description and comparison with other taxa are provided; therefore, it agrees with Articles 10 and 13 of the ICZN.

The binomial is regarded as genera inquirenda in the database mollusca-database.eu, possibly on the basis that the doubtful identity requires further investigation.

Plate XXVI, figure 2; page 249

Phanerotrema tomkeieffi Lamont, 1978

Figure 4.6-9

NMS G.1876.42.58.1: Henderson Collection; Deerhope Burn.

Lamont (1978) recognised that his specimen was very close to the species balteata. Nevertheless, he decided to erect a new species tomkeieffi based on a "better developed spire, which looks like the dome of a Russian cathedral." Comparison with Phanerotrema balteata (Phillips) indicates that there are no differences that can warrant a new species, especially based on a single specimen. Therefore, Phanerotrema tomkeieffi is regarded as subjective synonym of $P$. balteata.

Plate XXVI, figure 3; page 251

Eckfordius scoticus Lamont, 1978

Figure 5.1-4

NMS G.1982.20.4: Deerhope Burn, Deerhope Formation; Lamont Collection.

The name is not supported by a diagnosis, the description is minimal ("keels finely tuberculate", p. 251 ) and certainly not diagnostic, and the comparison with other taxa is very superficial. Therefore, Eckfordius scoticus is a nomen dubium.

The WMSDB and mollusca-database.eu regard the name as valid and it is classed within Pleurotomariidae.

Plate XXVI, figure 4; page 252

Gyronema cuthberti Lamont, 1978

Figure 5.5-7

NMS G.1982.20.2: Deerhope Burn; on label locality as R265 (but this is not along the Deerhope Burn); Lamont Collection.

Lamont (1978) closely compared G. cuthberti to $G$. duplicatum Ulrich and Scofield (a subjective synonym of $G$. semicarinatum Salter, according to the Paleobiology Database). The differences were based on few features of ornament.

Ebbestad (2007) figured this specimen and synonymized it with Gyronema salteri (Haswell, 1865) a common species in the Pentland Hills, particularly in the lower Member of the Wether Law Linn Formation (especially locality R260, although present in R82, R263 and R265). No discussion there referred to Lamont's species, and the locality 


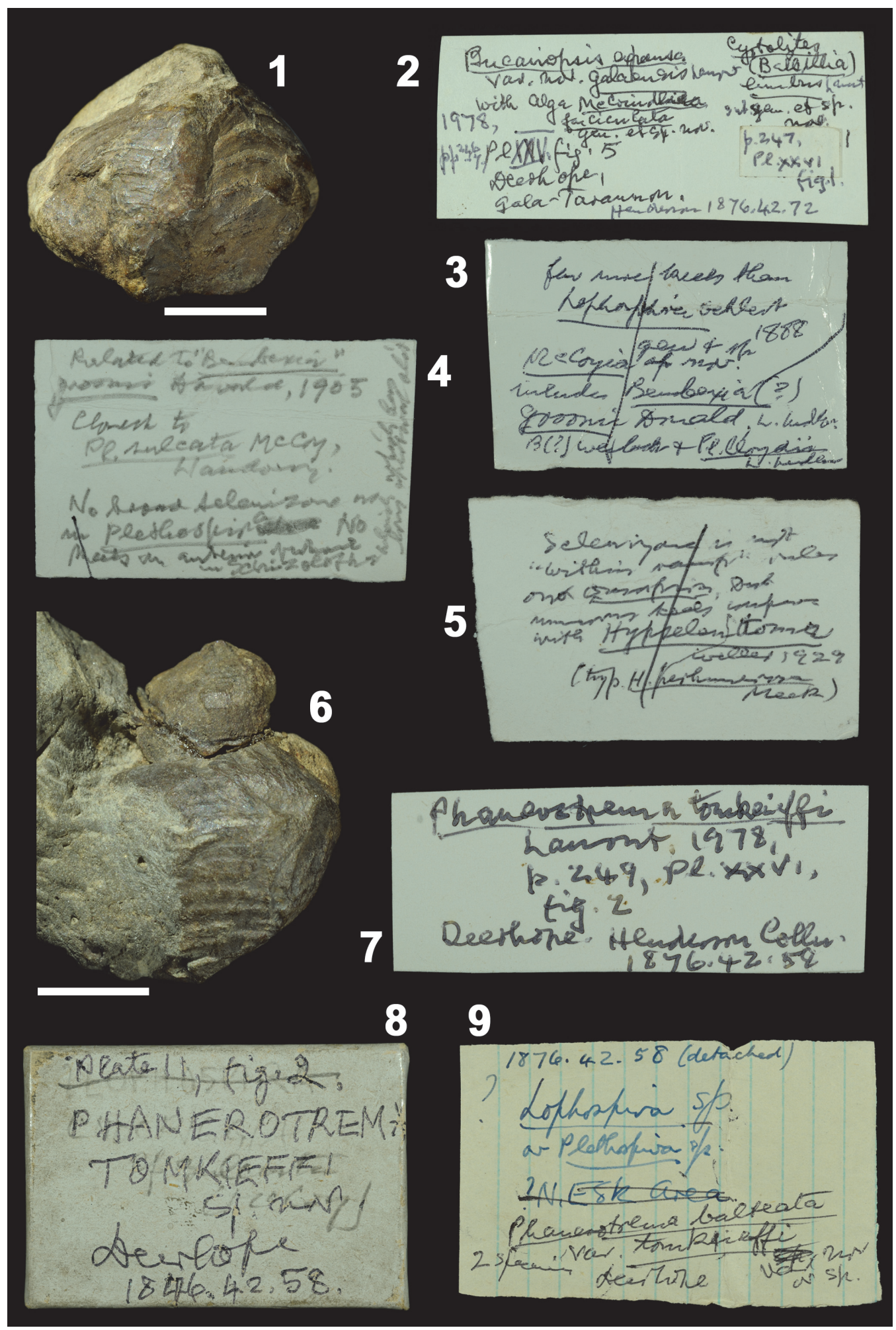

FIGURE 4. 1-5: Cyrtolites (Balsillia) limbus Lamont, 1978, from the Deerhope Burn; 1: side view of specimen NMS G.1876.42.72.2 from the Henderson Collection; 2: handwritten label associated with the specimen (right hand side); 3-5: handwritten labels discussing the possible affinity of the specimen (see Lamont 1978, page 247) - note that the information on some labels is crossed out by Lamont. 6-9: Phanerotrema tomkeieffi Lamont, 1978, from the Deerhope Burn; 6: side view of specimen NMS G.1876.42.58.1 from the Henderson Collection; 7-9: handwritten labels associated with the specimen. Scale bars: $5 \mathrm{~mm}$ (figures 1,6). 


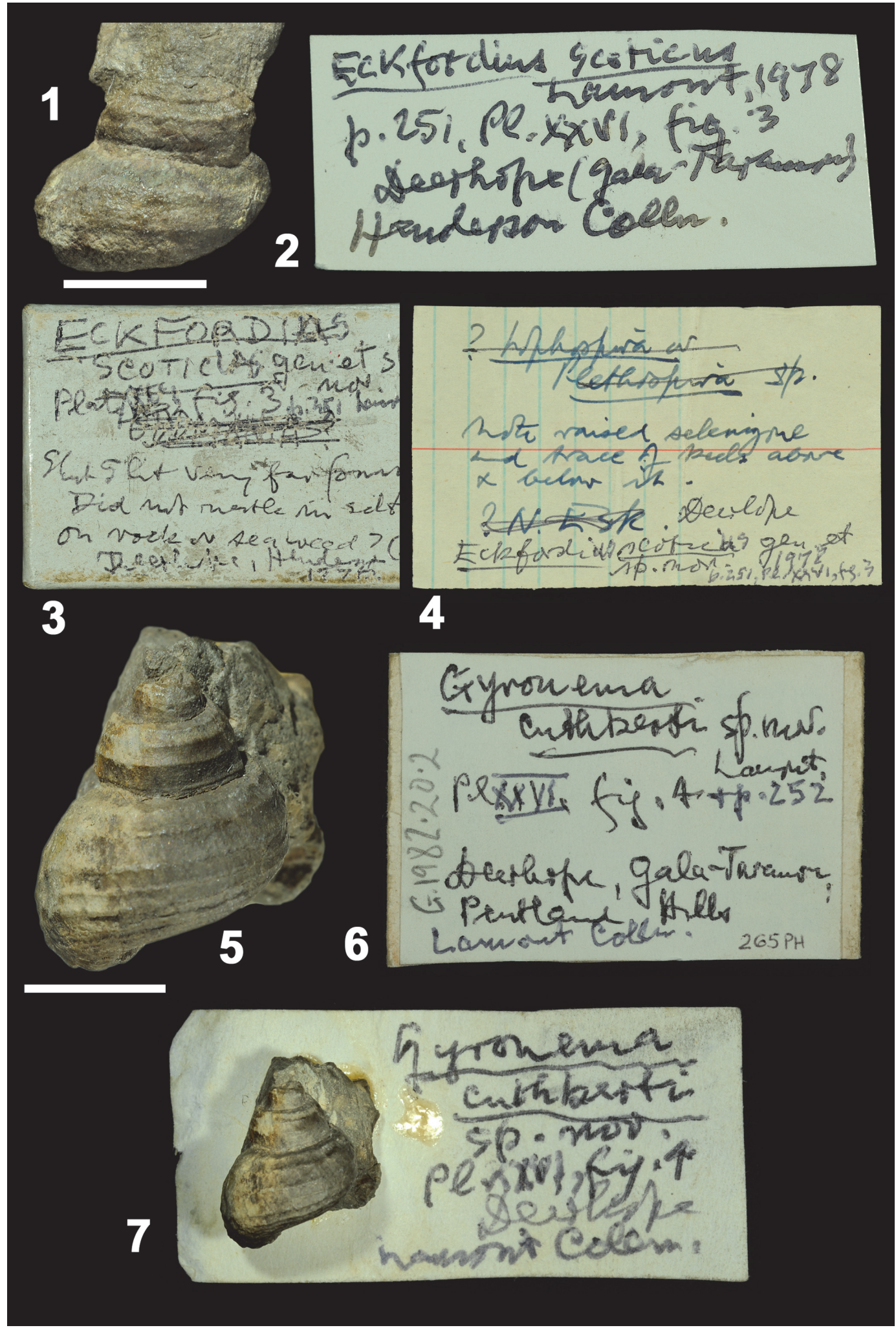

FIGURE 5. 1-4: Eckfordius scoticus Lamont, 1978, from the Deerhope Burn, Deerhope Formation; 1: side view of specimen NMS G. 1982.20.4 from the Henderson Collection; 2-4: handwritten labels associated with the specimen. 5-7: Gyronema cuthberti Lamont, 1978, from the Deerhope Burn; 5: side view of specimen NMS G.1982.20.2 from the Lamont Collection; 6, 7: handwritten labels associated with the specimen - note the specimen is glued to the label as it is often the case with collections acquired from Lamont. Scale bars: $5 \mathrm{~mm}$ (figures 1,5). 


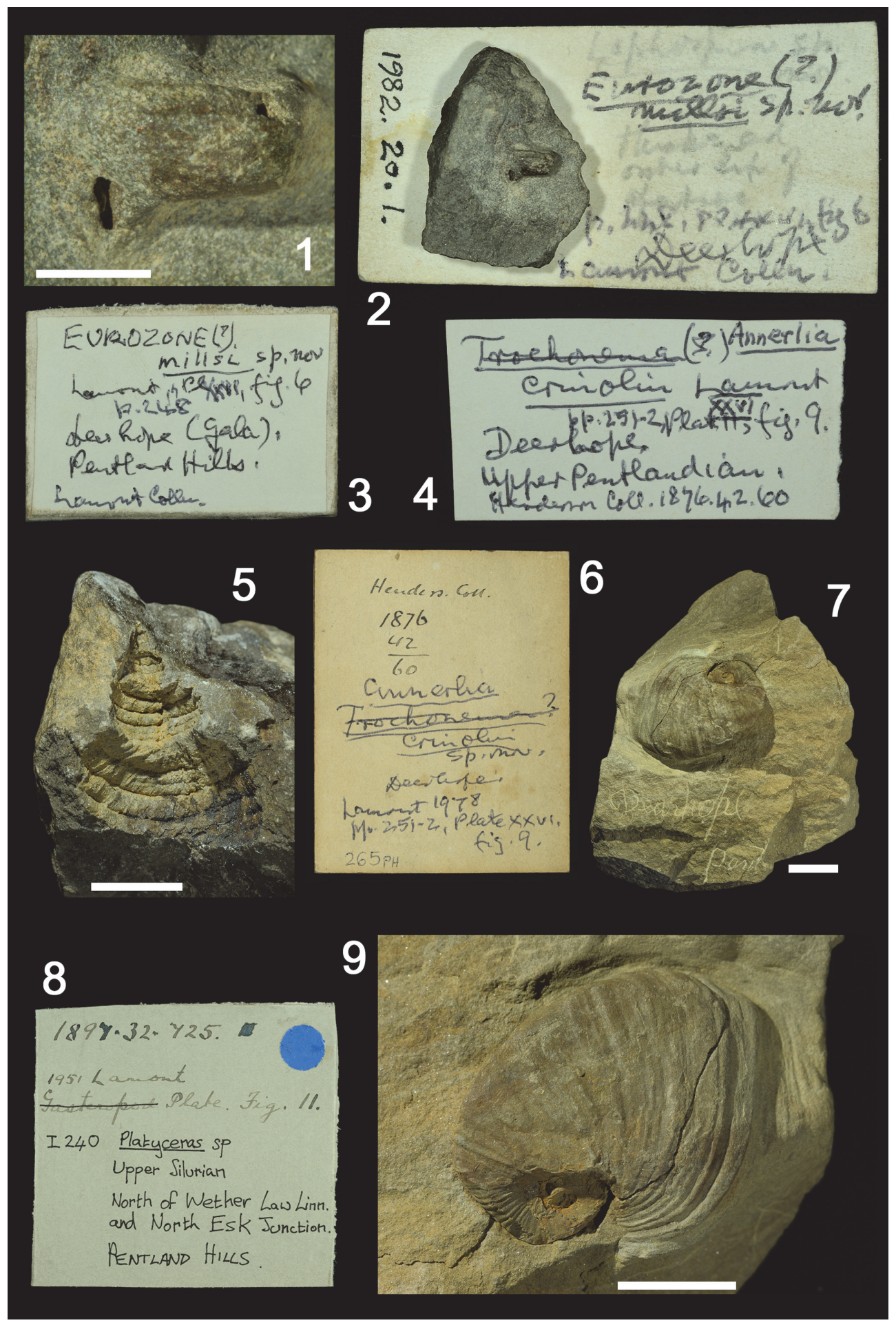

FIGURE 6. 1-3: Euryzone? millsi Lamont, 1978, from the Deerhope Burn; 1, 2: side view of possibly the last whorl (possibly apertural view, although the aperture is not preserved) of specimen NMS G.1982.20.1 from the Lamont Collection - note the specimen is glued to the label; 3: handwritten label associated with the specimen. 4-6: Annerlia crinolin Lamont, 1978, from the Deerhope Burn; 4, 6: handwritten labels associated with the specimen - image 6 shows the back of the label on which the specimen was glued; 5: External mould of the side view of specimen NMS G.1876.42.60 from the Henderson Collection. 7-9: Platyceras (Acroculia?) antiquata Salter, 1861, from locality R82, Wether Law Linn Formation; 7, 9: adapertural views of specimen NMS G.1897.32.725 from the Hardie Collection note "Deerhope Pentland" is engraved on the matrix (image 7); 8: handwritten label associated with the specimen. Scale bars: $10 \mathrm{~mm}$ (figures 7, 9); $5 \mathrm{~mm}$ (figure 5); $2 \mathrm{~mm}$ (figure 1). 
was recorded as $\mathrm{R} 260$, which is located along the Deerhope Burn. Note that the holotype was recorded from R82 (locality $\mathrm{H}$ in Haswell 1865). Here we follow Ebbestad's (2007) re-identification of the specimen based on identical spiral shape and ornamentation.

According to mollusca-database.eu, the genus belongs to Holopeidae.

According to WMSDB and Bouchet and Rocroi (2005), it belongs to Lophospiridae.

Specimen figured by Ebbestad (2007), plate 19, fig. 2.

Plate XXVI, figure 5; page 248

Cockriggia trilineata Lamont, 1978

Specimen is not traced.

Lamont provides the reader with a diagnosis and a basic comparison of his taxon; therefore, the name can be regarded as valid.

This binomial name is listed in WMSDB and ranked within the Archaeogastropoda (unassigned). In mollusca-database.eu, the genus is classed within the Gosseletinidae.

Plate XXVI, figure 6; pagel 248
Euryzone? millsi Lamont, 1978

Figure 6.1-3

NMS G.1982.20.1: Deerhope Burn; Lamont Collection.

Lamont (1978) did not justify the erection of a new species in his remarks. The paucity and poor preservation of the material does not warrant a new species. This species should be regarded as nomen nudum. Lamont used an alternative (wrong) spelling in his labels (Figure 6.2-3).

The genus is ranked within the Gosseletinidae according to Bouchet and Rocroi (2005).

Plate XXVI, figures 7, 8; page 252

Gyronema? peerie Lamont, 1978

Specimen is not traced.

This species is based on a poorly preserved, incomplete specimen (body whorl, or part of it, preserved only). This species does not fulfil Articles 10 and 13 of the ICZN, and is regarded as nomen nudum.

\section{Plate XXVI, figure 9; page 251 \\ Annerlia crinolin Lamont, 1978}

Figure 6.4-6

NMS G.1876.42.60: Deerhope Burn; locality indicated on labels as R265 (however, it is not situated along the Deerhope Burn); Henderson Collection.

Lamont (1978) failed to provide a description/ diagnosis of his new taxon and a comparison with other taxa. Therefore, his new genus is regarded as nomen nudum.

This specimen may be related to Gyronema (note in collection: "Gyronema sp. Checked with J. Peel").

Plate XXVI, figure 10; page 252

Platyceras (Acroculia?) antiquata Salter, 1861 Figure 6.7-9

NMS G.1897.32.725: locality "Deerhope" is engraved on the matrix of the specimen. Has this been recorded according to Haswell's (1865) map (where the NW branch of the North Esk River is labelled as Deerhope)? A label associated with the specimen reads the locality as "North of Wether Law Linn and North of North Esk junction. Therefore, it is likely locality R82; Wether Law Linn Formation; Hardie Collection. This species was collected from locality R87 (locality L) by Haswell (1865, p. 25).

Lamont (1978) hinted a parasitic relationship between Platyceras and a large organism. The gastropod Platyceras has long been regarded as a fossil curiosity because of a common association with crinoids (Thompson, 1970). The association between crinoids and these gastropods was first described by Austin and Austin (1843) who believed that crinoids were carnivorous and had died while feeding on the gastropod. Trautschold (1867) was the first to suggest that the gastropod may have been coprophagous or was dependent on the crinoid for food. Several authors established later that the gastropod was sedentary upon the crinoid and was at least feeding in part upon the crinoid excrement (see also Thompson, 1970, for summary). Bowsher (1955) also noted the sedentary nature of the gastropod and that the aperture of the gastropod shell (marked by "re-entrants and salients") corresponded to the irregularities of the surface of attachment. More recently, Baumiller (2003) demonstrated the parasitic/coprophagous interaction between Platyceras and pinnulate crinoids, rather than a predator/prey relationship.

Plate XXVI, figure 11; page 253

Hormotoma henshawi Lamont, 1978

Figure 7.2

Specimen is not traced in the National Museums Scotland collections, but specimen GSE 10707 from the British Geological Survey collection looks like the specimen illustrated by Lamont. GSE 10707 is an external mould of a specimen, whereas Lamont appears to have drawn the cast of an exterior. The specimen is figured here. 


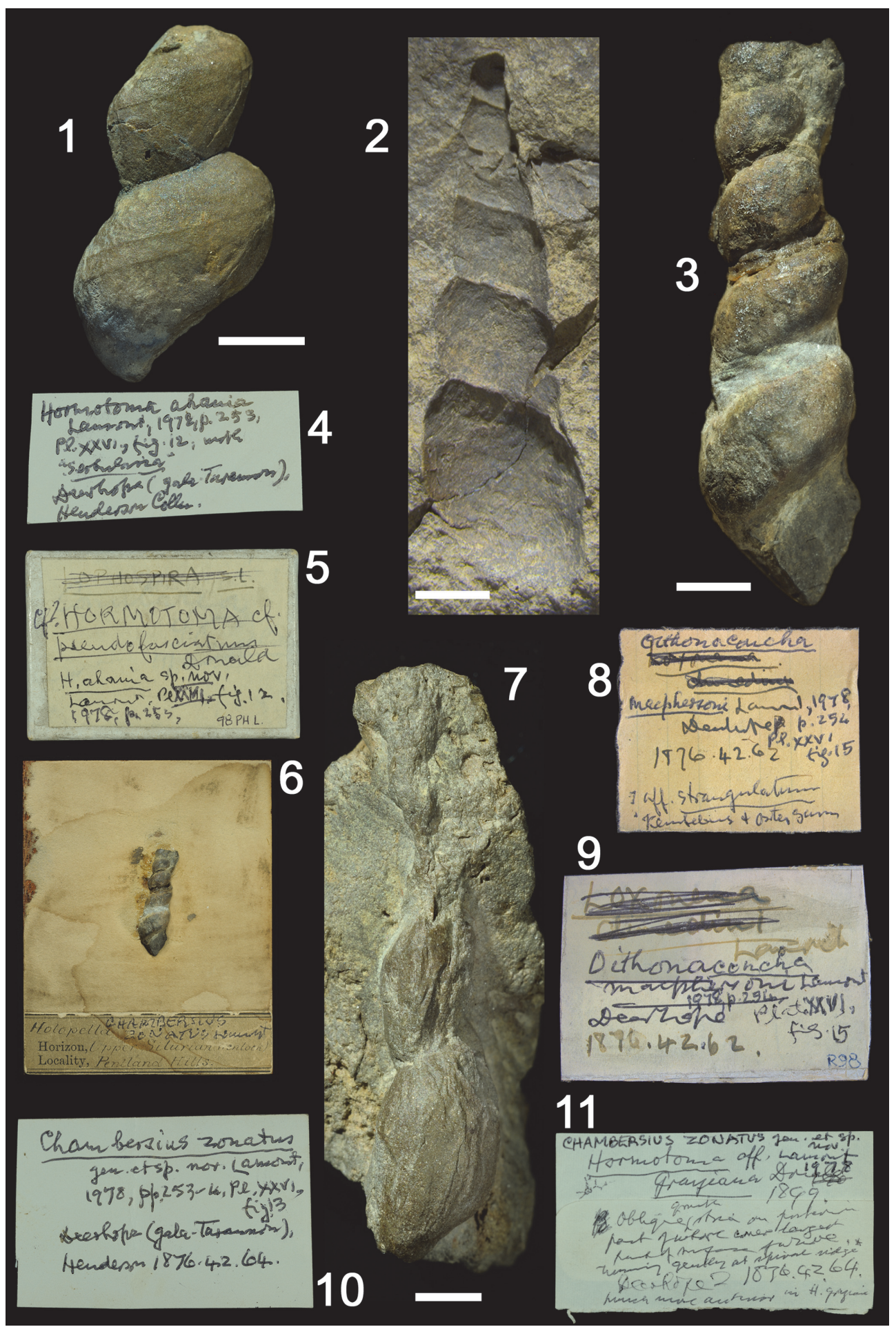

FIGURE 7. 1, 4, 5: Hormotoma ahania Lamont, 1978, from the Deerhope Burn or possibly locality R98, Henshaw Burn, Wether Law Linn Formation; 1: side view of specimen NMS G.1876.42.64 from the Henderson Collection; 4, 5: handwritten labels associated with the specimen. 2: Hormotoma henshawi Lamont, 1978, from the Henshaw Burn, Wether Law Linn Formation, side view of specimen BGS GSE 10707. 3, 6, 10, 11: Chambersius zonatus Lamont, 1978, from the Deerhope Burn; 3, 6: possibly apertural view of specimen NMS G. 1876.42 .64 from the Henderson Collection - note the specimen is glued onto a label (image 5); 10, 11: handwritten labels associated with the specimen. 7-9: Oithonaconcha macphersoni Lamont, 1978, from the Deerhope Burn, or possibly locality R98, Henshaw Burn, Wether Law Linn Formation; 7: side view of specimen NMS G.1876.42.62.1 from the Henderson Collection; 8, 9: handwritten labels with information regarding the specimen. Scale bars: $5 \mathrm{~mm}$ (figures 1, 2); $2.5 \mathrm{~mm}$ (figures 3, 7). 
According to Lamont the locality is as follows: "under the Mono[c]limacis cf. crenulata bed at the Henshaw Burn"; or "Henshaw Burn, about $2 \mathrm{ft}$ below layer with Monoclimacis cf. crenulata", therefore the specimen likely was collected from the Wether Law Linn Formation.

Lamont provided a succinct description of the species (smooth whorls, growthlines, slit band about half the length of final whorl), and therefore it should be regarded as valid.

Plate XXVI, figure 12; page 253.

Hormotoma ahania Lamont, 1978

Figure 7.1, 4, 5

NMS G.1876.42.62.2: locality not mentioned by Lamont (1978), but a label mentions "Deerhope". A separate note on the specimen box indicates the locality as R98, along the Henshaw Burn, and corresponds to the upper Wether Law Linn Formation; Henderson collection.

Lamont (1978), although erecting a new species based on that single specimen, compared it closely to Hormotoma pseudofasciatum (Donald) (see specimen box, Figure 7.5). In his 'Remarks', he compared it to Hormotoma gracilis (Hall), but noted a much wider band in the new species. Hall (1847) noted a "carinal band upon the centre of the volution with curving striæ above and below" ( $p$. 181); however, this feature is poorly illustrated on either plate 39 or plate 83 , but visible only on plate 39 figure 4c. There is a selenizone (Hall's carinal band) at mid-whorl height similar to that of $\mathrm{H}$. gracilis, although in the Scottish specimen there are no "curving striæ" visible, and to that of Murchisonia (Hormotoma) sp. B in Peel (1973).

Lamont (1978) provided a description and comparison of the new taxon, fulfilling articles 10 and 13 of the ICZN. This species can be regarded as valid, although based on a single specimen, which does not allow observing any possible intraspecific variations that would help in defining a new species.

Plate XXVI, figure 13; page 253

Chambersius zonatus Lamont, 1978

Figure 7.3, 6, 10, 11

NMS G.1876.42.64: Deerhope Burn; Henderson Collection.

This specimen has initially been referred to Holopella (see label, Figure 7.6). However, the type species $H$. gracilior M'Coy, 1851 is characterised by smooth spires (no selenizone) and less deep suture than the present specimen. Lamont's specimen is poorly preserved, but there is a narrow selenizone high on the whorl near the suture with the previous whorl (posterior part of the whorl). In that aspect it is similar to Hormotoma griffithi Donald from the Llandovery of Cong, Co. Mayo, Ireland, which is a coeval species to the present.

Another label (Figure 7.11) by A. Lamont identifies the specimen as $H$. aff. grayiana Donald, but Donald (1899) characterised her species with a selenizone low on the whorl, towards the anterior part of the whorl.

Lamont's (1978) taxon is not described and comparisons with other taxa do not emphasise the diagnostic differences of his new taxon. Therefore, this taxon is regarded as nomen nudum. The specimen is re-identified as Hormotoma sp.

Plate XXVI, figure 14; page 254

Girvania jacobea Lamont, 1978

Specimen not traced: Lamont records the specimen as NMS G.1876.42.62.

The identity of the specimen is questionable as according to Lamont his illustration is a "reconstruction from a poorly preserved external mould" (p. 254). The species is regarded as nomen nudum as there is no description or comparison of the taxon.

\section{Plate XXVI, figure 15; page 254 \\ Oithonaconcha macphersoni Lamont, 1978} Figure 7.7-9

NMS G.1876.42.62: Deerhope Burn according to Lamont (see labels Figure 7.8, 7.9) or R98 (along the Henshaw Burn) according to a more recent NMS label (origin unknown, but later than 1989).

Lamont provided a description of the specimen, but no comparison that would distinguish his taxon from other Loxonematoidea. The specimen was originally identified as Loxonema by Lamont and according to a more recent label, it was confirmed as Loxonema by John Peel in 1997.

The museum register lists the specimen as Loxonema elegans M'Coy, but Lamont (1947) differentiated "a Loxonema in the North esk area" with "slightly less sinous growth lines than $L$. elegans McCoy, which is the Wenlock form" (p. 206), without any other clue. Ebbestad (2007) described Loxonema sinuosum (Sowerby in Murchison, 1839) from the Deerhope and Wether Law Linn formations, but unfortunately the characteristic ornamentation is not visible on the present specimen. In absence of more specimens, we regard Lamont's specimen as Loxonema macphersoni (Lamont).

Plate XXVII, figures 1, 2; page 250

Polytropina splad Lamont, 1978

Figure 8.1-2 

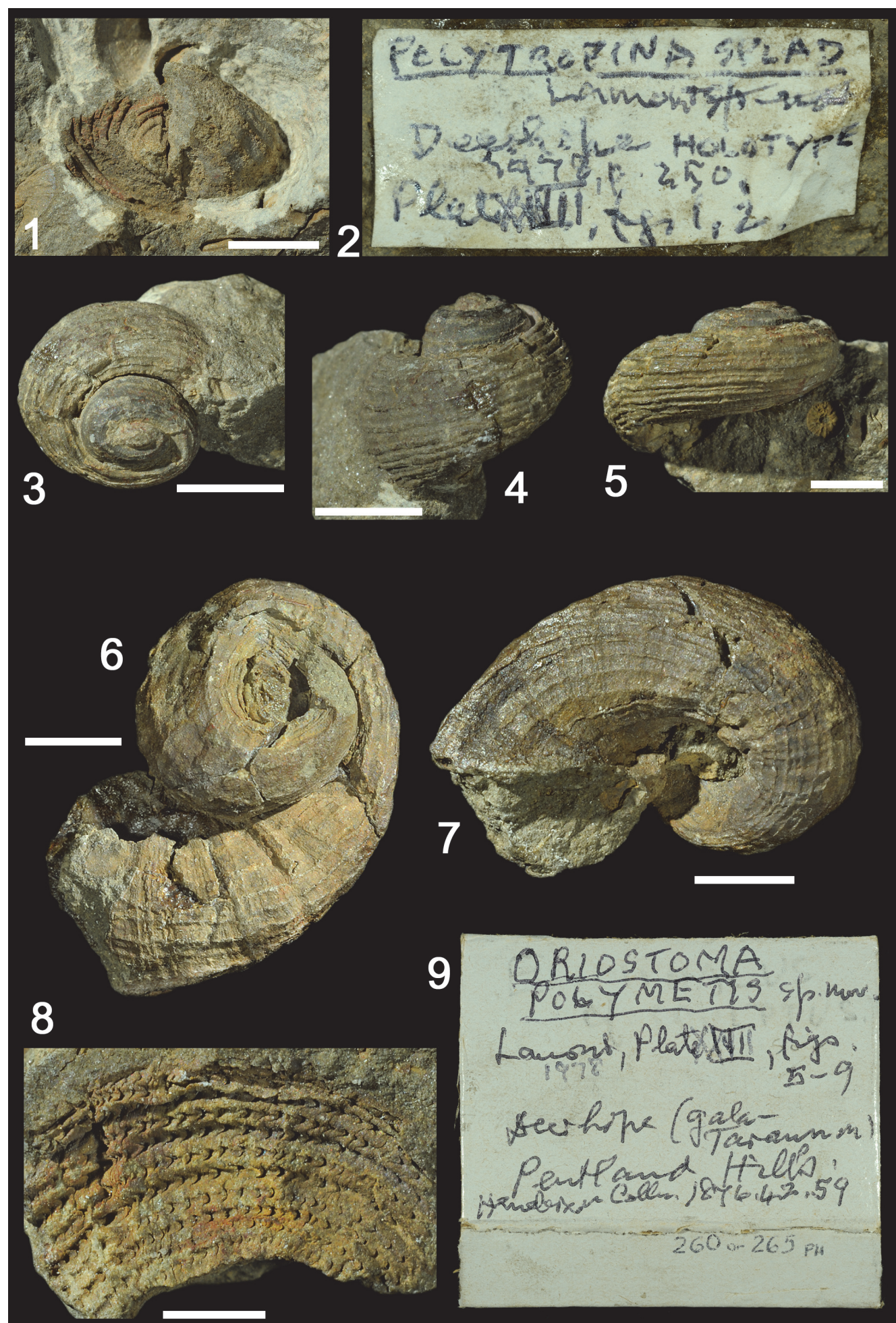

$$
\begin{aligned}
& \text { seciho (Gala- Tanmon } \\
& \text { Pent and Hollo } 199
\end{aligned}
$$

$$
260 \%-263 \mathrm{pH}
$$

FIGURE 8. 1, 2: Polytropina splad Lamont, 1978, from the Deerhope Burn; 1: specimen NMS G.1982.20.3 from the Lamont Collection (figured on plate XXVII, figures 1, 2); 2: handwritten label glued on and associated with the specimen. 3-9: Oriostoma polymetis Lamont, 1978, from the Deerhope Burn, NMS G. 1876.42.59 from the Henderson Collection; 3-5: apical and side views of juvenile specimen (figured as plate XXVII, figure 5); 6-7: apical and umbilical views of mature specimen (figured on plate XXVII, figures 6,7 ); 8: detail of ornaments on external moulds (figured on plate XXVII, figure 8); 9: handwritten label associated with the specimen, locality, and publication reference. Scale bars: $5 \mathrm{~mm}$ (figures 1, 3, 4, 6, 7); $2.5 \mathrm{~mm}$ (figures 5, 8). 


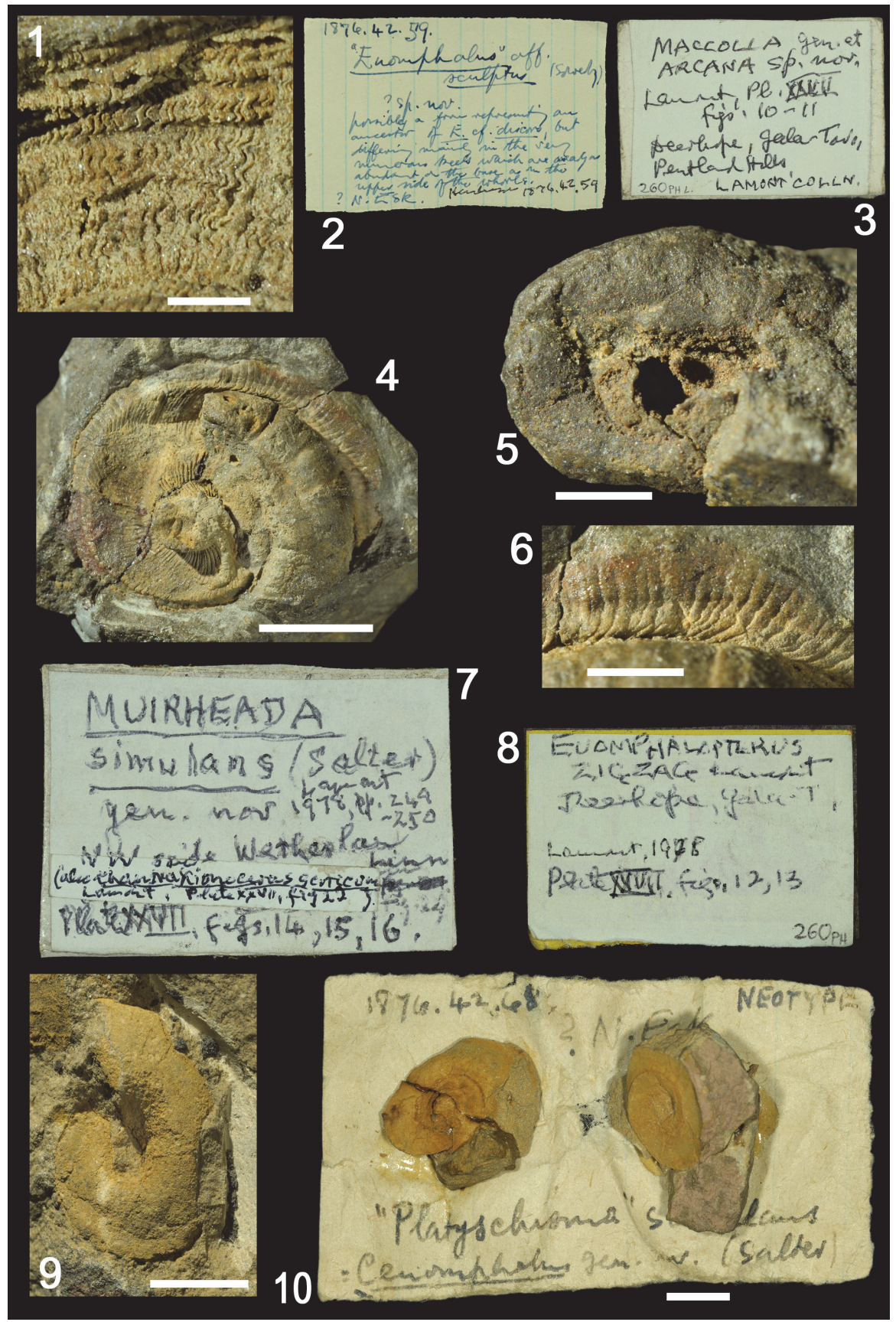

FIGURE 9. 1-2: Oriostoma polymetis Lamont, 1978, from the Deerhope Burn, NMS G. 1876.42.59 from the Henderson Collection; 1: detail of ornaments on external moulds (figured on plate XXVII, figure 9); 2: handwritten label discussing the possible affinities of the specimen - label reading "...possibly a form representing an ancestor of $E$. cf. discors, but differing mainly in the very numerous keels which are nearly as abundant on the base in the upper side of the whorls...". 3, 5: MacColla arcana Lamont, 1978, from the Deerhope Burn, locality R260, Wether Law Linn Formation; 3: handwritten label associated with the specimen; 5: specimen NMS G.1979.77.2 from the Lamont Collection (figured on plate XXVII, figures 10, 11). 4, 6, 8: Euomphalopterus zigzag Lamont, 1978, from the Deerhope Burn, locality R260, Wether Law Linn Formation; 4, 6: specimen NMS G.1977.77.1 from the Lamont Collection, mould of umbilicus and shell, and detail of ornament (figured on plate XVII, figures 12-13); 8: handwritten label associated with the specimen. 7, 9, 10: Muirheada simulans (Salter, 1861) from possibly locality R98 (described by Lamont, 1978, as "NW side Wether Law Linn, above Deerhope horisons" [sic], page 288), upper part of the Wether Law Linn Formation; recorded as specimens NMS G.1876.42.68 from the Henderson Collection; 7: handwritten label referring to the specimens; specimen on figure 9 is figured by Lamont on plate XXVII, figure 14; specimens on figure 10 are figured by Lamont on plate XXVII, figures 15, 16. Scale bars: $5 \mathrm{~mm}$ (figures 4, 9, 10); $2.5 \mathrm{~mm}$ (figure 1); $2 \mathrm{~mm}$ (figures 5, 6). 
NMS G.1982.20.3: locality engraved on the specimen as R265, along the Wether Law Linn, lower part of the Wether Law Linn Formation. A label associated with the specimen mentions the origin as Deerhope Burn, Deerhope Formation. No locality information from Lamont's article.

There is a typographic error on the genus name on page 250 (Polytropins), which is the first occurrence of the name in the text.

Lamont compared his specimen closely with Polytropina conferta Lamont, 1946, from the 'Penkill Group' (upper Llandovery) of Penkill Gorge, Girvan, without discussing any morphological differences that would warrant his new species. Lamont failed to provide a description and, therefore, partly fails to adhere to the ICZN rules regarding new species. The species name should be regarded as nomen nudum.

According to the WMSDB, the genus is regarded as objective synonym and re-assigned to Poleumita Clarke and Ruedemann, 1903, and belongs to the Euomphalidae. Bouchet and Rocroi (2005; p. 241) regarded the family Euomphalidae as "uncertain position within the Mollusca (Gastropoda?)".

Plate XXVII, figures 3, 4; page 250

Oriostoma ocellus Lamont, 1978

Specimen is not traced. Locality unknown.

Lamont did not describe the species, but only compared it very briefly to $O$. discors. The species cannot be accepted as valid and should be regarded as nomen nudum.

Plate XXVII, figures 5-9; page 251

Oriostoma polymetis Lamont, 1978

Figure 8.3-9; Figure 9.1-2

NMS G.1876.42.59: Deerhope Burn; Henderson collection.

Lamont proposed two different species of Oriostoma without comparing them to each other. Oriostoma ocellus has not been located and, therefore, cannot be compared to O. polymetis here. The species polymetis was described on the basis of a single specimen and was compared to $O$. lautus without expressing the differences between the two species. This species is described here as nomen dubium until more material is available, and a more thorough description and comparisons can be undertaken.

Plate XXVII, figures 10, 11; page 251 MacColla arcana Lamont, 1978

Figure 9.3, 5
NMS G.1979.77.2: Deerhope Burn, locality R260; Wether Law Linn Formation; Lamont collection. It is probable that the specimen was registered a second time, and was originally NMS G.1876.42.55.2, identified as Euomphalus sculptus, from the Henderson collection.

Lamont attempted a description of this poorly preserved specimen, but did not compare it to any known taxa. Lamont's new taxon is here regarded as nomen dubium as the 'type' specimen lacks any diagnostic features.

According to John Peel, this specimen cannot be identified (pers. comm. to museum 2004 [museum label in the collection])

Plate XXVII, figures 12, 13; page 249

Euomphalopterus zigzag Lamont, 1978

Figure 9.4, 6, 8

NMS G.1979.77.1: Deerhope Burn, locality R260; Wether Law Linn Formation; Lamont collection. The specimen may have been registered a second time and possibly was NMS G.1876.42.55.1, and originally identified as Euomphalus sculptus, from the Henderson collection.

The part that is preserved consists of the body whorl below the keel (including the keel). According to Lamont, it is similar to Euomphalopterus alatus var. subundulatus (Salter) based on the ornament, with the growth lines curving sharply back under the keel. It also possesses a wide umbilicus. Ebbestad (2007) compared closely the Pentland Hills specimen with Euomphalopterus apedalensis Pitcher, 1939 and included Lamont's specimen within Euomphalopterus cf. apedalensis. We follow Ebbestad (2007) recommendation here.

Specimen figured by Ebbestad (2007) on plate 17, fig. 9 .

Plate XXVII, figures 14-16; page 249

Muirheada simulans (Salter, 1861)

Figure 9.7, 9, 10

NMS G.1876.42.68: Henderson Collection; locality described by Lamont as "NW side Wetherlaw Linn, above Deerhope horisons" [sic] (page 288). The species was originally described as Platyschisma, but Lamont did not discuss the differences with his new genus. Haswell (1865) has described Platyschisma simulans from localities $\mathrm{F}$ and $\mathrm{L}$, which correspond to localities R67 (Cock Rig Formation) and R87 (Wether Law Linn Formation), both along the North Esk River. The species was recorded by Peach et al. (1910) from Band $\mathrm{H}$ of Henderson and Brown, a few yards from the foot of the junction between the North Esk and Henshaw Burn along the latter. Band $\mathrm{H}$ corresponds to the uppermost 


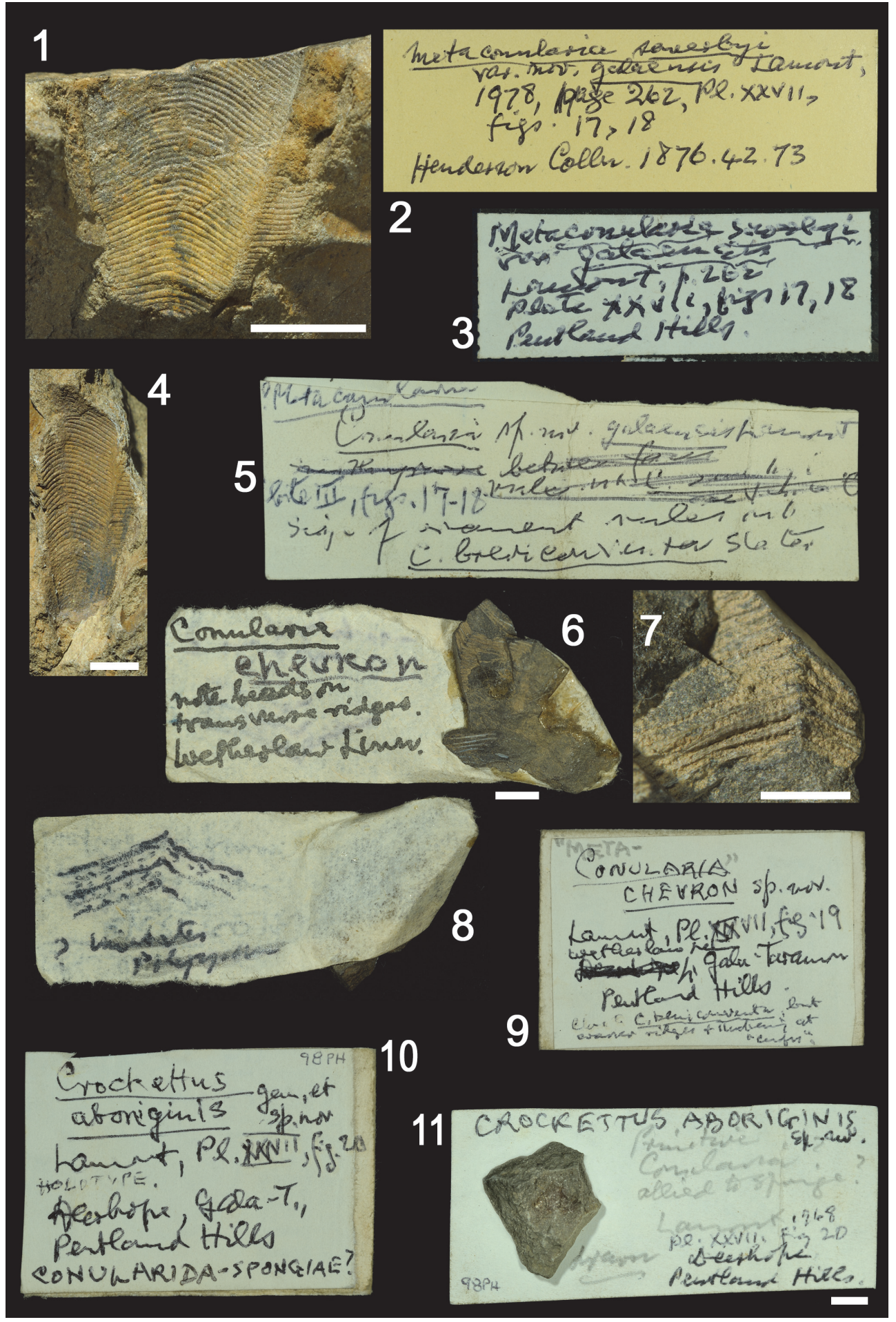

FIGURE 10. 1-5: Metaconularia sowerbyi var. galaensis Lamont, 1978; 1: specimen NMS G.1876.42.73.1 figured by Lamont on plate XXVII figure 17; 4: specimen NMS G.1876.42.73.2 figured by Lamont on plate XXVII, figure 18; 2, 3, 5: handwritten labels referring to the specimens. Specimens figured from the Henderson Collection. 6-9: Conularia chevron Lamont, 1978, from the Wether Law Linn; 6-8: specimen NMS G.1979.77.14 from the Lamont Collection, showing specimen glued on label (6), close-up of specimen (7) that is figured by Lamont on plate XXVII, figure 19, and reverse of label (8) shown on figure 6; 9: handwritten label with details of the specimen. 10, 11: Crockettius aboriginis Lamont, 1978, from the Deerhope Burn, possibly locality R98; 10: handwritten label with details of the specimen (genus name misspelled); 11: specimen NMS G.1979.77.15 glued on handwritten label (genus name misspelled), figured by Lamont on plate XXVII, figure 20. Scale bars: $5 \mathrm{~mm}$ (figures 1, 4, 6); $2.5 \mathrm{~mm}$ (figures 7, 11). 
part of the Wether Law Linn Formation. This may be locality R98 in the upper part of the Wether Law Linn Formation.

Lamont's remarks (p. 249) are not helpful in understanding his new genus; these remarks fail to conform to articles 10 and 13 of the ICZN. Therefore, Lamont's genus Muirheada is regarded as nomen nudum. The specimen is re-identified as Platyschisma simulans.

The genus is regarded as valid in molluscadatabase.eu and WMSDB and is classed within Euomphalidae. Lamont classed his species within Euomphalopteridae. According to Boucher and Rocroi (2005), Platyschisma belongs to the subfamily Platyschismatinae of the Sinuopeidae and is unassigned to a superfamily.

Plate XXVII, figures 17, 18; page 262

Metaconularia sowerbyi var. galaensis Lamont, 1978

Figure 10.1-5

NMS 1876.42.73.1 and NMS 1876.42.73.2: Henderson Collection.

Plate XXVII, figure 19; page 262

Conularia chevron Lamont, 1978

Figure 10.6-9

NMS G.1979.77.14: Lamont stated the Wether Law Linn as locality; Lamont Collection.

Plate XXVII, figure 20; page 262

Crockettius aboriginis Lamont, 1978

Figure 10.10-11

NMS G.1979.77.15: locality mentioned as Deerhope, R98 (see label); Lamont Collection.

Remarks for specimens figured on Plate XXVII, figures 17 to 20: The three species proposed by Lamont are not well described and morphologically not compared with one another. The specimens described as Conularia and Crockettius are poorly preserved, and only a small section of the flattened theca is visible. The specimens described as Metaconularia and Crockettius show an ornamentation of fine, node-bearing ribs (5 per $\mathrm{mm}$ ) arching towards the midline and slightly offset. In contrast, the specimen of Conularia possesses node-bearing ribs ( 3 per $\mathrm{mm}$ ) joining at the midline in an obtuse angle and not offset on each side of the midline. These are the main morphological differences that can be observed. Stewart et al. (2007) regarded the three specimens as belonging to C. hastata.

Van Iten (1992) observed that paired carinae were diagnostic of Metaconularia. This feature is not observed here in the specimens described as Metaconularia. All the specimens from the Pentland Hills possess a simple midline, i.e., it is not furrowed (see Van Iten, 1992) and a simple groove, which indicates that the specimens belong to the genus Conularia. Conularia hastata Slater, 1907, was described from the "River Esk below Henshaw Burn" (page 30) as "Ornamentation fine; ..., forming a broad curve across the face, flat in the centre, and falling to the marginal grooves, where they meet the ridges of the adjacent side at an angle of nearly $90^{\circ}$." and "Studded with very small, round, distant tubercules, from which fine, sharp lamellæ extend upwards across the furrow" (p. 29). The specimens described here as Metaconularia and Crockettius can clearly be characterised by these features. Therefore, they are very likely specimens of Conularia hastata and should be regarded as such. On the other hand, Slater (1907) also described Conularia subtilis Salter from the Silurian of England and Wales, and also figured a single specimen from the Deerhope Burn. This species is characterised by an ornamentation "forming an average angle of $130^{\circ}$ along the facial groove, and falling more sharply to the "lateral" than to the "central" marginal grooves" (p. 34). The ornament on the specimen described as Conularia chevron by Lamont is similar to that of $C$. subtilis. However, Slater (1907) believed that the specimen from Deerhope should be "placed apart as a definite variety" (p. 34). Until more complete material is collected that could allow a revision of the species, Conularia chevron is a nomen dubium.

Plate XXVII, figure 21

Anadontopsis [sic] cf. salteri [author and year of publication indet.]

Figure 11.1-2

NMS G.1979.45.4: locality R82, Wether Law Linn Formation; Lamont Collection

There is no 'Diagnosis' or 'Remarks' in Lamont's article. However, the specimen is clearly identifiable from the illustration due to the two short, parallel gouges.

The genus name was misspelled as Anadontopsis instead of Anodontopsis.

This specimen may be similar to Anodontopsis lucina Salter, 1861, and was erroneously identified as $A$. cf. salteri by Lamont, a binomen to which no reference can be found.

Plate XXVII, figure 22; page 260

Chantrakionoceras scoticum Lamont, 1978

Figure 11.3 


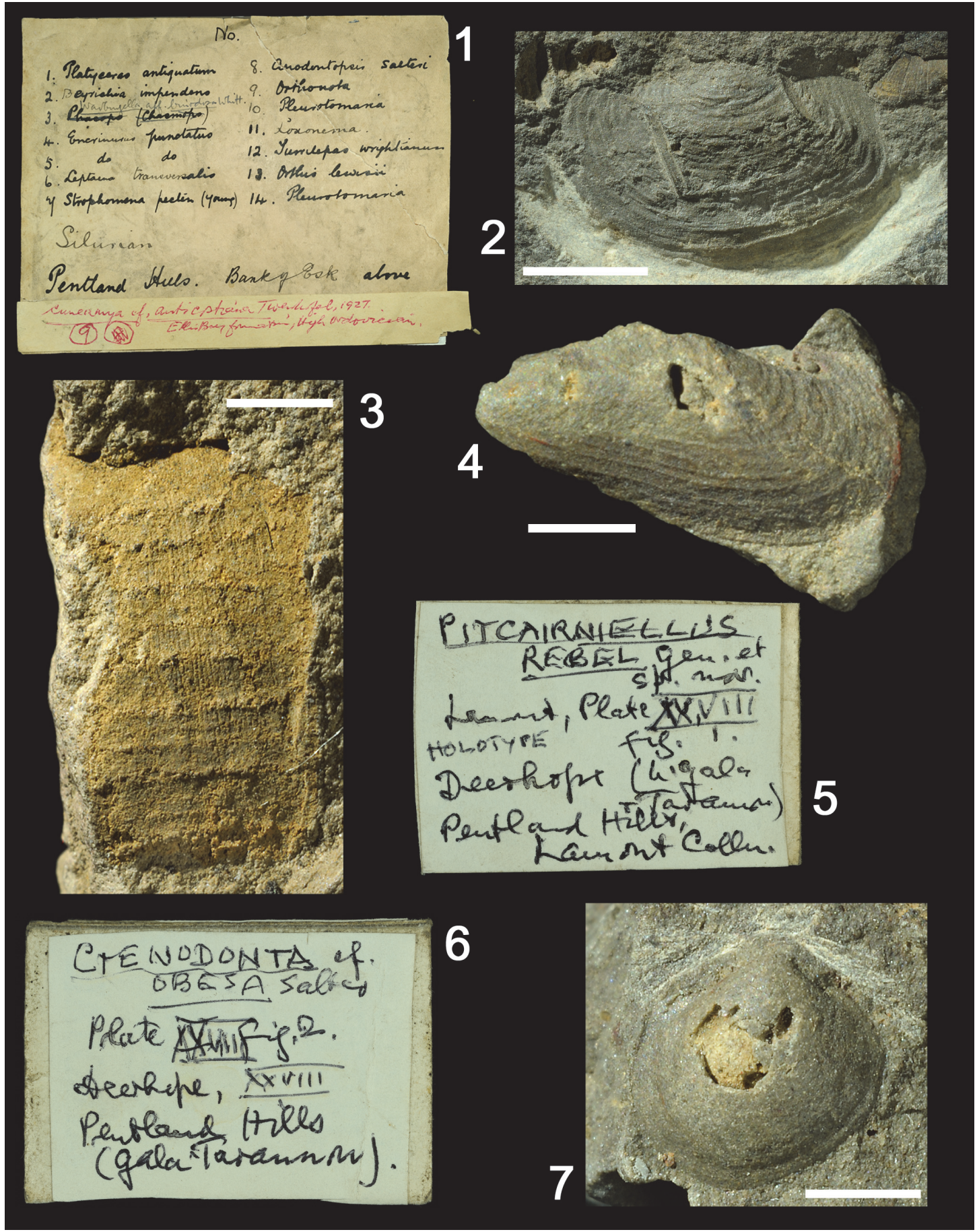

FIGURE 11. 1, 2: Anadontopsis cf. salteri from locality R82, Wether Law Linn Formation; 1: handwritten label (author unknown) with addendum (red ink) by A. Lamont - specimen referred to as number 8 on the label; 2: specimen NMS G.1979.45.4 from the Lamont Collection. 3: Chantrakionoceras scoticum Lamont, 1978, possibly from locality R98 (same locality as Muirheada simulans), upper part of the Wether Law Linn Formation; specimen NMS G.1876.42.68 from the Henderson Collection, figured by Lamont on plate XXVII, figure 22. Holland (2000) noted that the longitudinal ornament is placed across the page; the specimen's orientation is reproduced here as in Lamont's plate. 4, 5: Pitcairniellus rebel Lamont, 1978, from the Deerhope Burn; 4: specimen NMS G.1979.77.3 from the Lamont Collection, figured by Lamont on plate XVIII, figure 1; 5: handwritten label with information related to specimen. 6, 7: Ctenodonta cf. obesa Salter, 1861, from the Deerhope Burn; 6: handwritten label with information related to specimen; 7: specimen NMS G.1979.77.4 from the Lamont Collection, figured by Lamont on plate XXVIII, figure 2. Scale bars: $5 \mathrm{~mm}$ (figure 1), $2.5 \mathrm{~mm}$ (figures 3, 4, 7). 


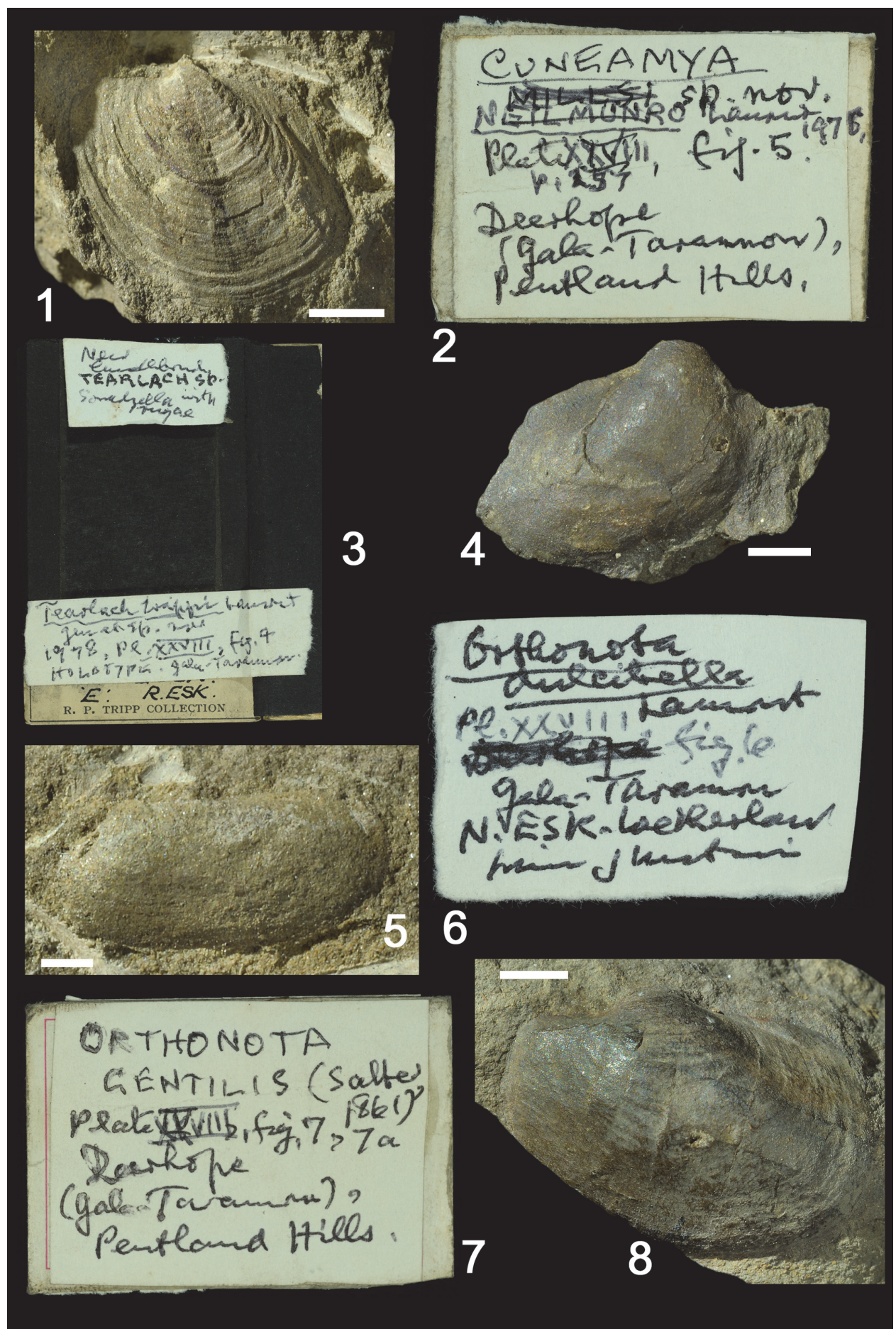

FIGURE 12. 1, 3: Tearlach trippi Lamont, 1978, from possibly locality R245 along the Deerhope Burn, Deerhope Formation; 1: specimen NMS G.1979.77.5 from the Lamont Collection, figured by Lamont on plate XXVIII, figure 4; 3: handwritten label with information on the specimen. 2, 4: Cuneamya neilmunro Lamont, 1978, from the Deerhope Burn, Deerhope Formation; 2: handwritten label with information on the specimen; 4: specimen NMS G.1979.77.8 from the Lamont Collection, figured by Lamont on plate XXVIII, figure 5. 5, 6: Orthonota dulcibella Lamont, 1978, from locality R82, Wether Law Linn Formation; 5: specimen NMS G.1979.77.9 from the Lamont Collection, figured by Lamont on plate XXVIII, figure 6; 6: handwritten label detailing the locality. 7, 8: Orthonota gentilis (Salter, 1861) from the Deerhope Formation; 7: handwritten label with information related to the specimen; 8: specimen NMS G.1979.77.10 from the Lamont Collection, figured by Lamont (1978) on plate XXVIII, figure 7. Scale bars: $2.5 \mathrm{~mm}$ (figures 1, 4, 8); 1 $\mathrm{mm}$ (figure 5). 
NMS G.1876.42.68: Henderson Collection. Same horizon and locality as Muirheada simulans illustrated by Lamont on plate 27, figure 14 .

According to Holland (2000), this specimen appears to be a fragment of kionoceratid. Although succinct, Lamont's remarks fulfill Article 13 of the ICZN and until more complete material is collected and described, Lamont's name is regarded valid.

Plate XXVIII, figure 1; page 255

Pitcairniellus rebel Lamont, 1978

Figure 11.4-5

NMS G.1979.77.3: Deerhope Burn; Lamont Collection.

Lamont provided a diagnosis of the new taxon and a comparison with other taxa; therefore, articles 10 and 13 of the ICZN are fulfilled, and this taxon can be regarded as valid, although more material should be collected to assess morphological variability.

Plate XXVIII, figure 2; page 256

Ctenodonta cf. obesa Salter, 1861

Figure 11.6-7

NMS G.1979.77.4: Deerhope Burn; Lamont Collection.

This specimen, although poorly preserved, is similar to C. obesa as described by Salter (1861), especially preserving at the posterior side a projection as in Salter (1861, plate 2, figure 12).

Plate XXVIII, figure 3; page 256

Eopterinopecten alindaba Lamont, 1978

Specimen is not traced. No locality details.

Lamont provided a description of the taxon, but no comparison with other taxa. The taxon is regarded as nomen dubium.

\section{Plate XXVIII, figure 4; page 256 \\ Tearlach trippi Lamont, 1978 \\ Figure 12.1, 3}

NMS G.1979.77.5: on the label locality as North Esk River, but mention of ' $E$ ' which may refer to Haswell's localities; this is equivalent to locality R245 along the Deerhope Burn (not called Deerhope Burn at the time of Haswell's study) in the Deerhope Formation; R.P. Tripp Collection.

This species was described on the basis of a single specimen. Lamont produced a diagnosis, but comparisons with other taxa are basic.

The specimen figured by Lamont and two others in the NMS palaeobiology collection (one is a part and counterpart) look like Grammysia obliqua Lamont, 1954, collected from a locality "128 yards east of the large Quarry in Haggis conglomerate, north-west of the North Esk Reservoir, Pentland
Hills, Scotland", which is equivalent to locality R55 along the North Esk River, in the Deerhope Formation. It is similar in the shape and orientation of the oblique sulcus and in the concentric ornament. Although in the present specimen it is not as marked, external moulds show the concentric ornament breaking up "into four strands as they cross the position of the anterior fold" (Lamont, 1954, p. 274 ) that is characteristic of G. obliqua sensu Lamont. The latter was reidentified as ?Tancrediopsis obliqua by Geldart et al. (2007, p. 92, pl. 12, figs. 11, 12).

Lamont's binomial had already been used by McCoy in 1852 for specimens that are significantly different from the Scottish specimens. Lamont's species is a junior homonym of McCoy's and, therefore, cannot be regarded as valid, and Grammysia obliqua McCoy has priority (see articles 52.2 and 52.3 of the ICZN).

This taxon is not listed in mollusca-database.eu or WMSDB.

Plate XXVIII, figure 5; page 257

Cuneamya neilmunro Lamont, 1978

Figure 12.2, 4

NMS G.1979.77.8: Deerhope Burn; Lamont Collection.

This single specimen was used to erect a new species and Lamont (1978) compared it briefly to C. holmesi from locality R55 (according to Geldart et al., 2007) in the Deerhope Formation. The illustrations are those of exteriors, not interiors as is the present specimen; therefore, comparisons are difficult to make. Lamont's species should be regarded as nomen dubium. Comparison with other material from the Pentland Hills suggests this specimen may be related to Nuculites.

This species is not listed in mollusca-database.eu or WMSDB.

\section{Plate XXVIII, figure 6; page 257 \\ Orthonota dulcibella Lamont, 1978 \\ Figure 12.5-6}

NMS G.1979.77.9: R. Tripp collection; or possibly re-registered from NMS G.1876.42.108, and identified as Orthonota rotunda, from the Henderson collection. Locality R82 ("N. Esk-Wetherlaw Linn junction"), Wether Law Linn Formation.

The preservation of this specimen is poor. Lamont compared it with Orthodesma semiradiata, noting that it is less elongate. The present specimen may be related to Orthodesma semiradiata as it possesses a clear oblique ridge and a gently convex ventral margin. More specimens are necessary to clarify the taxonomic position. Nevertheless, 


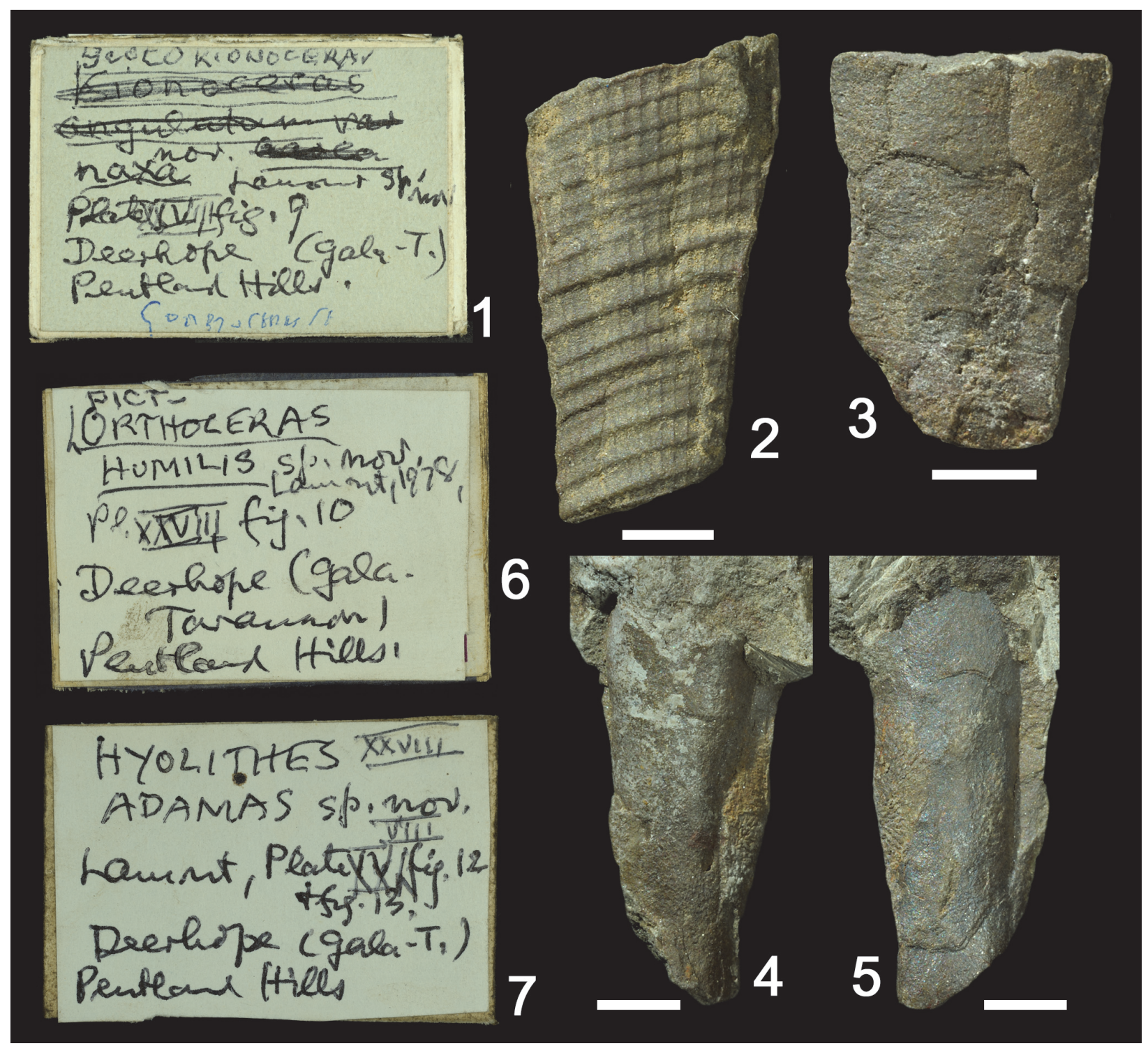

FIGURE 13. 1, 2: Scotokionoceras naxa Lamont, 1978, from the Deerhope Burn, Deerhope Formation; 1: handwritten label with information regarding the specimen; 2: specimen NMS G.1979.77.11 from the Lamont Collection, figured by Lamont on plate XXVIII, figure 9. 3, 6: Orthoceras (Pictorthoceras) humilis Lamont, 1978, from the Deerhope Burn, Deerhope Formation; 3: specimen NMS G.1979.77.13 from the Lamont Collection, figured by Lamont on plate XXVIII, figure 10; 6: handwritten label with details on the specimen. 4, 5, 7: Hyolithes adamas Lamont, 1978, from the Deerhope Burn, Deerhope Formation; 4, 5: front and reverse views of specimen NMS G.1979.77.16 from the Lamont Collection, figured by Lamont on plate XXVIII, figures 11, 12; 7: handwritten label with details on the specimen. Scale bars: $2.5 \mathrm{~mm}$ (figures 2-5).

Lamont's species conforms to the rules of the ICZN, and Orthonota dulcibella is a valid name.

Plate XXVIII, figure 7; page 258

Orthonota gentilis (Salter, 1861)

Figure 12.7-8

NMS G.1979.77.10 (possibly re-registered from NMS G.1876.42.101 and originally described as $O$. gentilis; Henderson Collection): Deerhope Formation; locality as "Pentland Hills" only.

This specimen differs from Salter's description and illustration of his new "variety". The present specimen is more quadrate, and the umbo is positioned around the middle of the hinge line. More specimens are needed to allow a clear identification. 


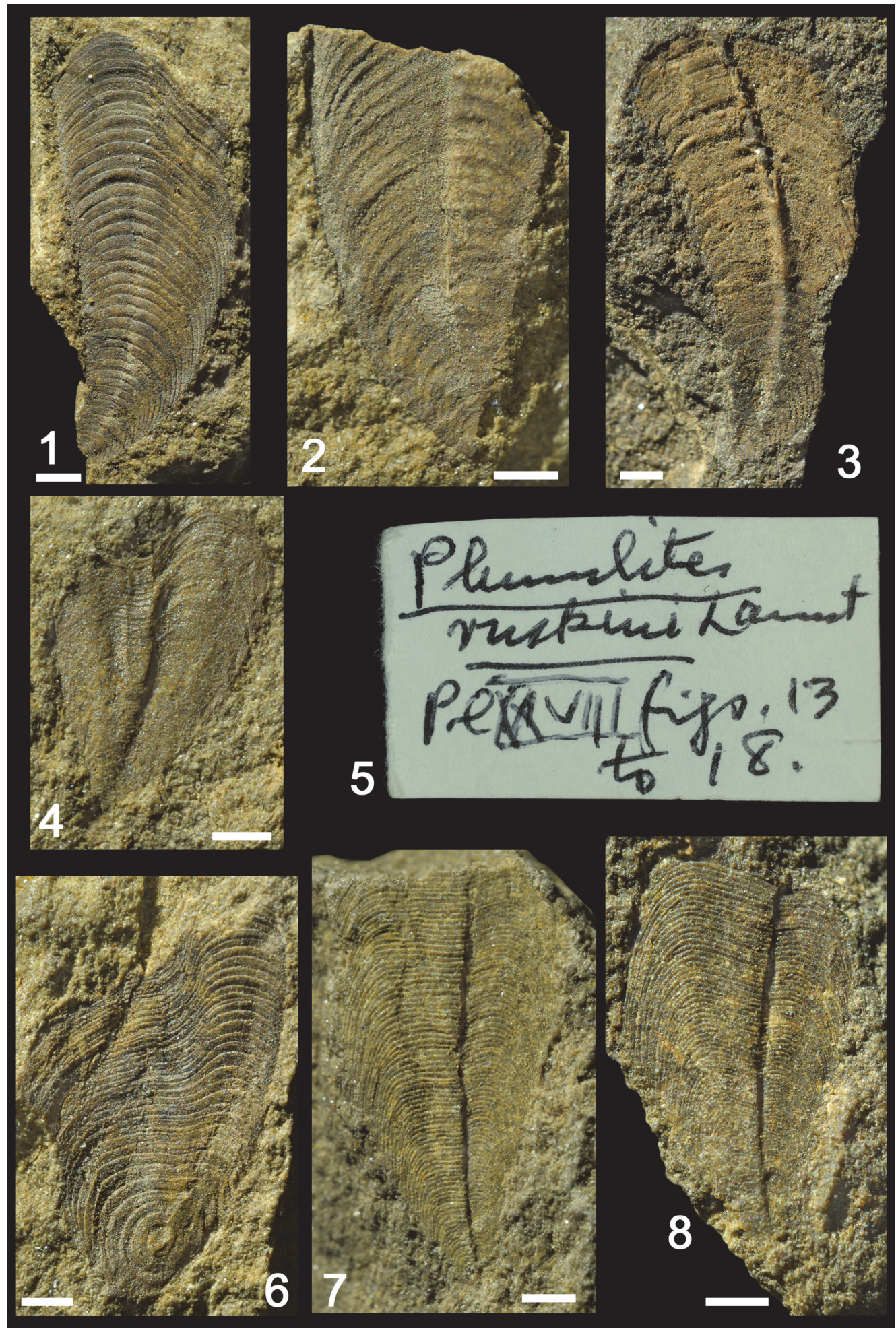

FIGURE 14. 1-8: Plumulites ruskini Lamont, 1978, from locality R82, Wether Law Linn Formation; 1, 2: specimen NMS G. 1979.77.17 (part and counterpart), figured by Lamont on plate XXVIII, figure 13; 3: specimen NMS G.1979.77.18, figured by Lamont on plate XXVIII, figure 14; 4: specimen NMS G.1979.77.19, figured by Lamont on plate XXVIII, figure 15; 5: handwritten label; 6: specimen NMS G.1979.77.20, figured by Lamont on plate XXVIII, figure 16; 7: specimen NMS G.1979.77.21, figured by Lamont on plate XXVIII, figure 17; 8: specimen NMS G.1979.77.22, not figured by Lamont. All specimens from the Lamont Collection, possibly re-registered from NMS G.1876.42.8 (Henderson Collection). Scale bars: $1 \mathrm{~mm}$ (figures 1-4, 6-8). 
Plate XXVIII, figure 8; page 258

Orthonota cf. bulla Salter, 1861

Specimen not located: locality and horizon as "the Brown Biscuit (Cystid) bed near the confluence of the Henshaw Burn with the North Esk." This is locality R98 in the upper part of the Wether Law Linn Formation.

Plate XXVIII, figure 9; page 258

Scotokionoceras naxa Lamont, 1978

Figure 13.1-2

NMS G.1979.77.11: Deerhope Formation, locality as Deerhope Burn. Although Holland (2000) located it as "Deerhope Burn, Pentland Hills", there is no indication that it was collected there. In the "Pentlands guide", Holland (2007) confessed that only a single specimen from the Pentland Hills is undoubtedly located from locality R260 along the Deerhope Burn. Nevertheless, a label hand written by Lamont indicates Deerhope (Burn) as locality.

Holland (2000, p. 183, figure $1 \mathrm{~g}$ ) assigned this specimen to Gorbyoceras sp., and we follow here his identification.

Plate XXVIII, figure 10; page 259

Orthoceras (Pictorthoceras) humilis Lamont, 1978

Figure 13.3, 6

NMS G.1979.77.13: Deerhope Formation, locality as Pentland Hills.

Holland (2000, p. 185) considered the specimen as "unidentifiable" and regards the taxon as nomen dubium.

Plate XXVIII, figures 11, 12; page 262

Hyolithes adamas Lamont, 1978

Figure 13.4, 5, 7

NMS G.1979.77.16, possibly re-registered from NMS G.1876.42.14 (described in the original specimen register as "Crustacean remains"): Deerhope Formation, locality as Pentland Hills.

Lamont compared his new species with other species of Hyolithes, but no proper description of his new species was undertaken and, therefore, does not fulfil Article 13 of the ICZN. The species is a nomen dubium.

Plate XXVIII, figures 13-18; page 263

Plumulites ruskini Lamont, 1978

Figure 14.1-8

NMS G.1979.77.18, 17, 19, 20, 22, 21, respectively: identified as Turrilepas wrightii in the original specimen register and registered as NMS G.1876.42.8, from the Henderson collection; Wether Law Linn Formation, locality R82.
Candela and Crighton (2015) described in more detail the shell plates figured by Lamont (1978), alongside more recently collected material and other specimens from the Henderson Collection. All these were grouped according to the shell plates' morphological characteristics (named 'Sclerite Type 1 to 9, and Type 10 added by Candela and Crighton, 2017). From these studies it was clear that Lamont's material belonged to different shell plate assemblages, hence different species. Plumulites ruskini Lamont was regarded as nomen dubium by Candela and Crighton (2015). Plumulites lamonti Candela and Crighton, 2017, was erected and includes specimens NMS G.1979.77.21 and 22 from Lamont's work.

NMS G.1979.77.19 was assigned to Compacoleus? sp., NMS G.1979.77.20 was assigned to 'Sclerite Type' 1, and NMS G.1979.77.17 and 18 were assigned to 'Sclerite Type' 2.

Plate XXIX, figure 1; page 261

Phragmocerina? worthyi Lamont, 1978

Specimen is not traced.

The specimen was re-identified as Phragmoceras ventricosum J. de C. Sowerby by Holland (2000, p. 185). A similar specimen to that collected by Lamont was collected from locality R101 in the upper part of the Wether Law Linn Formation (Holland, 2000, p. 185).

Plate XXIX, figure 2; page 261.

Tubiferoceras rogeri Lamont, 1978

Specimen is not traced.

The specimen was collected from the 'Gutterford Burn flagstones', which corresponds to the Deerhope Formation (possibly localities R245R248).

As no description was undertaken by Lamont, Article 13 of the ICZN is not fulfilled and the species is a nomen nudum. Moreover, the species was based on the collection of a single specimen.

Plate XXIX, figures 3-5; page 261

Protophragmoceras erskinei Lamont, 1978

Specimen not traced: no locality given.

Holland (2000, p. 184) regarded this species as valid, and emended and expanded the description of Lamont's species, based on material from the lower part of the Wether Law Linn Formation housed in the Geological Museum, Trinity College, Dublin and the Oxford University Museum. He illustrated this taxon (see fig. 1j, k) with specimens from the collections of the Geological Museum at Trinity College, Dublin, but these are clearly not the specimens figured by Lamont. 


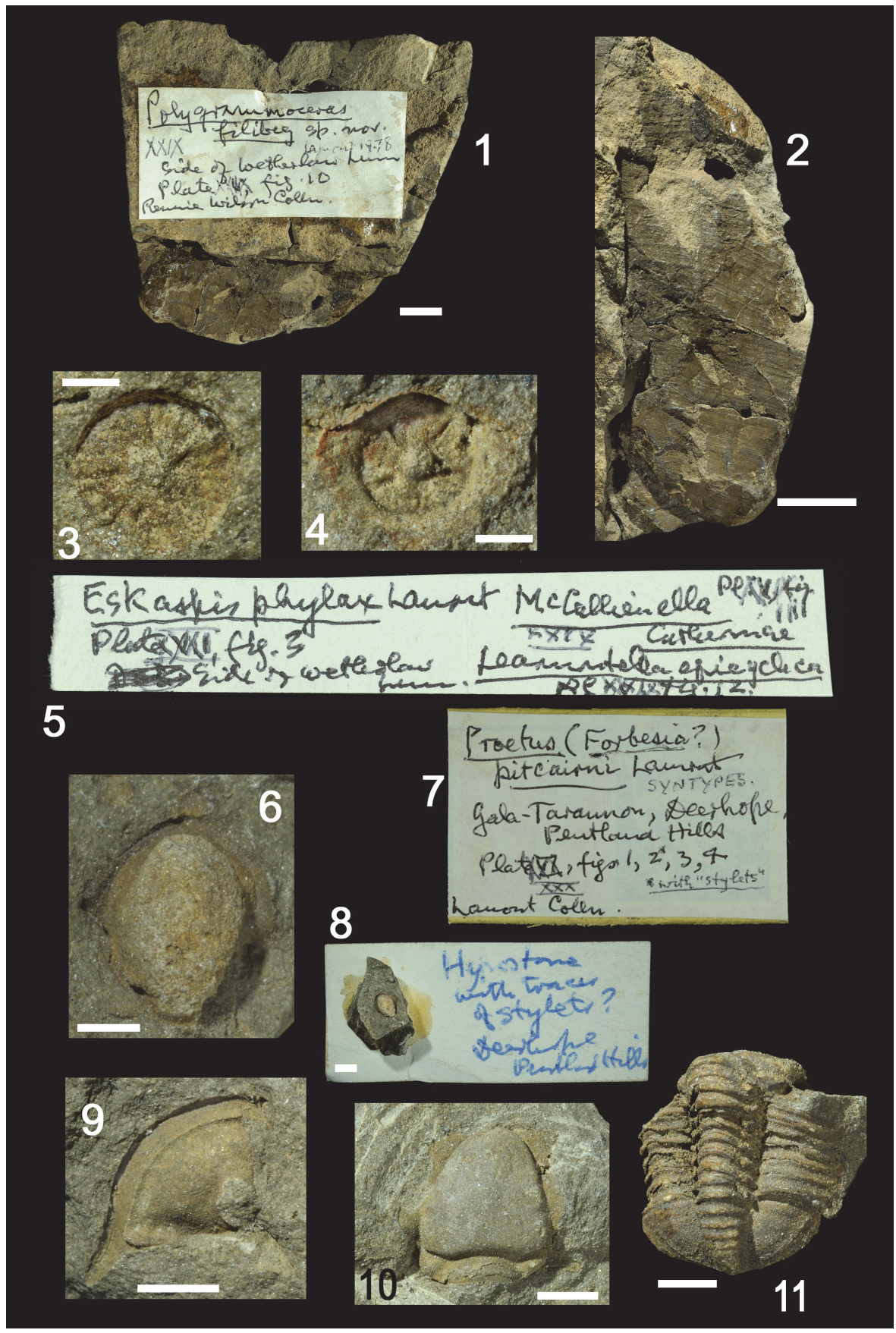

FIGURE 15. 1, 2: Polygrammoceras (Flettoceras) filibeg Lamont, 1978, from the Wether Law Linn, Wether Law Linn Formation; specimen NMS G.1979.77.12 from the Lamont Collection, figured by Lamont on plate XXIX, figure 10, showing view of the sample (including handwritten label) (1), and close-up of the specimen (2). 3, 5: McCallienellus catherinae Lamont, 1978, from the Wether Law Linn, Wether Law Linn Formation; 3: specimen NMS G.1979.77.36.2 from the Lamont Collection, figured by Lamont on plate XXIX, figure 11; 5: handwritten label with taxonomic name misspelled. 4, 5: Learmontella epicyclica Lamont, 1978, from the Wether Law Linn, Wether Law Linn Formation; 4: specimen NMS G.1979.77.36.3 from the Lamont Collection, figured by Lamont on plate XXIX, figure 12; 5: handwritten label. 6-11: Proetus (Forbesia?) pitcairni Lamont, 1978, from the Deerhope Burn (possibly R260), Wether Law Linn Formation; all specimens from the Lamont Collection; 6, 8: specimen NMS G.1979.77.24, figured by Lamont on plate XXX, figure 2, and label with specimen glued; 7: handwritten label with information related to the specimens; 9: specimen NMS G.1979.77.25, figured by Lamont on plate XXX, figure 3; 10: specimen NMS G.1979.77.23, figured by Lamont on plate XXX, figure 1; 11: specimen NMS G.1979.77.26, figured by Lamont on plate XXX, figure 4. Scale bars: $5 \mathrm{~mm}$ (figures 1, 2); $2 \mathrm{~mm}$ (figures 8-11); $1 \mathrm{~mm}$ (figure 6); $0.5 \mathrm{~mm}$ (figures 3, 4). 
Plate XXIX, figure 6; page 260

Gomphoceras monboddo Lamont, 1978

Specimen is not traced.

This species was re-assigned to 'Gomphoceras' sp. by Holland (2000, p. 185) on the basis of "the absence of the specimens and lack of information on the apertures." Holland misspelled this species as monobodda, whereas in Lamont it is consistently recorded as monboddo.

Lamont's new species was given after James Burnett, Lord Monboddo (1714-1799), who was an Edinburgh judge and a scholar in evolutionary linguistics.

Plate XXIX, figures 7, 8; page 260

Hexameroceras scotorum Lamont, 1978

Specimen preserved in the Lapworth Museum, University of Birmingham, BU 549. Wether Law Linn Formation, Henshaw Burn.

This species was re-assigned to Octameroceras scotorum (Lamont, 1978) by Holland (2000, $p$. 183), who provided a description of the species and re-figured Lamont's specimen on figure $1 \mathrm{f}$.

Plate XXIX, figure 9; page 260

Patieoceras patiei Lamont, 1978

Specimen is not traced.

This species was re-assigned to 'Gomphoceras' sp. by Holland (2000, p. 185) on the basis of "the absence of the specimens and lack of information on the apertures."

Plate XXIX, figure 10; page 259

Polygrammoceras (Flettoceras) filibeg Lamont, 1978

Figure 15.1-2

NMS G.1979.77.12, Rennie Wilson collection: Wether Law Linn, Wether Law Linn Formation.

This species was re-assigned to Geisonoceras maclareni by Holland (2000, p. 185), who could not see any justification for the erection of a new taxon.

Plate XXIX, figure 11; page 264

McCallienellus catherinae Lamont, 1978

Figure 15.3, 5

NMS G.1979.77.36.2: Wether Law Linn (exact locality unknown); horizon more than likely Wether Law Linn Formation.

The species was misspelled by Lamont in the plate explanation and a handwritten label as McCallienella catherinae.

Plate XXIX, figure 12; page 264

Learmontella epicyclica Lamont, 1978

Figure 15.4-5
NMS G.1979.77.36.3: Wether Law Linn (exact locality unknown); horizon more than likely Wether Law Linn Formation.

Plate XXIX, figure 13; page 264

Vallasius disjectus Lamont, 1978

Specimen not traced: 'Biscuit (or Cystid) bed', Henshaw Burn (exact locality unknown).

The species was incorrectly spelled in the plate explanation as Wallasius disjectus.

Plate XXIX, figure 14; page 264

Gabbatha hoplites Lamont, 1978

Specimen not traced: 'Biscuit (or Cystid) bed', Henshaw Burn (exact locality unknown).

Remarks for Plate XXIX, figures 11 to 14 : Donovan (2011) commented on the taxonomic misplacement of these four species (or specimens as each species is presented on the basis of a single specimen collected) into the Class Carpoidea. The specimens 'described' by Lamont are moulds of pelmatozoan plates or columnals.

The statement that "Lamont's original specimens have not been located in the collections of the National Museums of Scotland, Edinburgh (S.E. Stewart, written comm. to S.K.D., 29 November 2007)" was likely the result of the Royal Masterplan Project when the collections were being packed in advance of the closure of the National Museum of Scotland from 2008 until 2011. From 2008 the collections were not easily accessible until their relocation to the National Museums Collection Centre and progressive unpacking from 2010 onward. The entirety of the palaeobiology collections is now unpacked and accessible. Since Paul and Donovan (2011) two of these four specimens have been relocated by the present authors. Nevertheless, Paul and Donovan (2011, p. 440) regarded these four species as "probably junior synonyms of taxa described from more complete specimens," invalid, and "in an extreme sense, nomina invalida."

According to Paul and Donovan (2011), Lamont's 'Biscuit (or Cystid) bed' corresponds to the uppermost Cock Rig Formation, exposed at locality R260 along the Deerhope Burn, although Lamont indicates it from the Henshaw Burn, which would mean corresponding to the upper Wether Law Linn Formation.

Plate XXX, figures 1-4; page 265.

Proetus (Forbesia?) pitcairni Lamont, 1978 Figure 15.6-11 


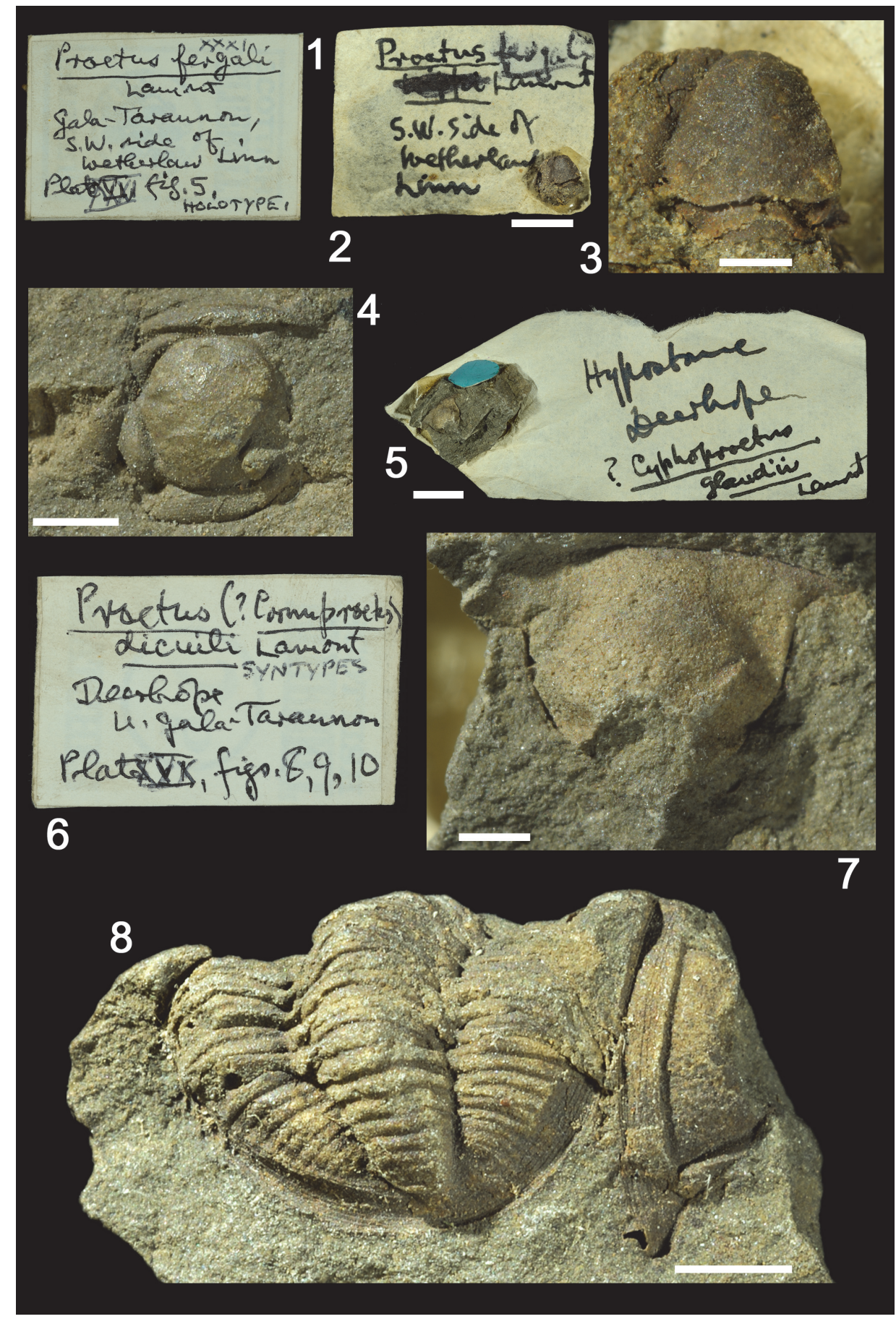

FIGURE 16. 1-3: Proetus (Scotoproetus) fergali Lamont, 1978, from the Wether Law Linn (possibly R265), Wether Law Linn Formation; 1, 2: handwritten labels with information on the specimen; 3: specimen NMS G.1979.77.27 from the Lamont Collection, figured by Lamont on plate XXX, figure 5. 4, 5, 7: Cyphoproetus (Carlopsia) glaudii Lamont, 1948; 4: specimen NMS G.1979.45.4 from locality R82, Wether Law Linn Formation, figured by Lamont on plate XXX, figure 6; this specimen is referred to on a label reproduced here on Figure 11.1 (\#3 on the list shown);" 5, 7: specimen NMS G.1979.77.31 (Lamont Collection) from the Deerhope Burn (possibly R260), Wether Law Linn Formation, glued to a handwritten label, and close-up of the hypostome, figured by Lamont on plate XXX, figure 7. 6, 8: Proetus (Cornuproetus) dicuili Lamont, 1978, from the Deerhope Formation (possibly R260), Wether Law Linn Formation; 6: handwritten label with information on the specimen; 8: specimens NMS G.1979.77.29 (pygidium) and NMS G.1979.77.30 (free cheek), figured by Lamont on plate XXX, figures 9 and 10; both specimens from the Lamont Collection. Scale bars: $5 \mathrm{~mm}$ (figures 2, 5); $2 \mathrm{~mm}$ (figures 4, 7, 8); $1 \mathrm{~mm}$ (figure 3). 
NMS G.1979.77.23-26: horizon unknown, but possibly Wether Law Linn Formation; locality stated as Deerhope Burn, possibly R260.

This species was re-assigned to Proetus (Lacunoporaspis) sp. by Clarkson and Howells (1981, p. 510), although they felt that the specific name pitcairni may be available. They left it under open nomenclature until more material becomes available.

Morris (1988, p. 189) synonymised the following four species pitcairni, fergali, dicuili and peeblesi with Proetus (Lacunoporaspis) peeblesi (Lamont, 1948).

Although Lamont did not provide an exact locality along the Deerhope Burn that would have allowed to determine the horizon of collection, Clarkson and Howells (1981) synonymised P. (F.?) pitcairni with a species (under open nomenclature) only found in the lower part of the Wether Law Linn Formation. Therefore, the specimens here are believed to originate from this formation.

Plate XXX, figure 5; page 266

Proetus (Scotoproetus) fergali Lamont, 1978 Figure 16.1-3

NMS G.1979.77.27: Wether Law Linn Formation; locality described as "S.W. side of Wether Law Linn", possibly R265.

Lamont (1978) noted the possibility that $P$. (F.?) pitcairni may be related to $P$. (S.) fergali. This species was also, like $P$. pitcairni, re-assigned to Proetus (Lacunoporaspis) sp. by Clarkson and Howells (1981, p. 510).

Plate XXX, figures 6, 7; page 267

Cyphoproetus (Carlopsia) glaudii Lamont, 1948 Figure 16.4, 5, 7

NMS G.1979.45.4 (figured on plate XXX, figure 6): Wether Law Linn Formation; the locality is described as "North Esk above Wether Law Linn junction, Pentland Hills," which corresponds to locality R82. However, Lamont (1948, p. 6) cited the locality as "Deerhope".

NMS G.1979.77.31 (figured on plate XXX, figure 7): locality as Deerhope; no horizon information.

The locality was recorded as the Deerhope Burn by Morris (1988) [may be R 260].

In the text, Lamont (1978) noted that this was a new species. Nevertheless, it had been mentioned in Lamont (1948), and the plate caption corrects this earlier mistake. In the latter no description was proposed, but the former provided a diagnosis.

Clarkson and Howells (1981, p. 512) reassigned this species to either Cyphoproetus comitilis Clarkson and Howells, 1981 (see page 512) or Cyphoproetus cf. depressus (Barrande, 1846) (see page 515), because the "specimens upon which Lamont based the name $C$. glaudii, though available, are now so badly abraded that it is not possible to tell from these whether the species presented is $C$. cf. depressus or C. comitilis." (p. 514). Clarkson and Howells (1981) regarded this species as nomen nudum and "the name glaudii should be suppressed" (p. 509).

However, in the synonymy list for $C$. cf. depressus, the illustration reference for Lamont's glaudii is not that of glaudii as in Lamont (1978), but partly of $P$. (F.) pitcairni.

Morris (1988) did not recognise the subgenus Carlopsia as valid, and synonymised C. comitilis Clarkson and Howells, 1981, with C. glaudii.

Figured by Lamont (1948; plate 1, figure 3) as Cyphoproetus glaudii.

NMS G.1979.45.4 is figured by Clarkson and Howells (1981) on plate 78, figure 10 as Cyphoproetus cf. depressus.

Plate XXX, figures 8-10; page 266

Proetus (Cornuproetus) dicuili Lamont, 1978 Figure 16.6, 8

NMS G.1979.77.28-30: horizon unknown, but possible Wether Law Linn Formation; locality stated as Deerhope Burn, possibly R260.

This species was, like $P$. pitcairni and $P$. fergali, re-assigned to Proetus (Lacunoporaspis) sp. by Clarkson and Howells (1981, p. 510).

Plate XXX, figure 11; page 267

Cyphoproetus cf. punctillosus (Lindström, 1885) Figure 17.1-2

NMS G.1979.77.32: locality as Deerhope Burn ("Deerhope, Pentland Hills"); horizon unknown.

This species was re-assigned to Cyphoproetus comitilis Clarkson and Howells, 1981.

Plate XXX, figure 12; page 267

Cyphoproetus (Otademus) alacer Lamont, 1978

Figure 17.3-4

NMS G.1979.77.33: horizon described as "Gutterford Burn flagstones with Chonetes", which is equivalent to the Deerhope Formation, Deerhope Coral Beds; locality as Deerhope Burn, which indicates possibly locality R247.

This species was synonymised with Acernaspis sp. by Clarkson and Howells (1981, p. 526). However, Morris listed these with Acernaspis alacer (Lamont), and therefore regarded Otadenus as junior subjective synonym (see also Jell and Adrain, 2002). 


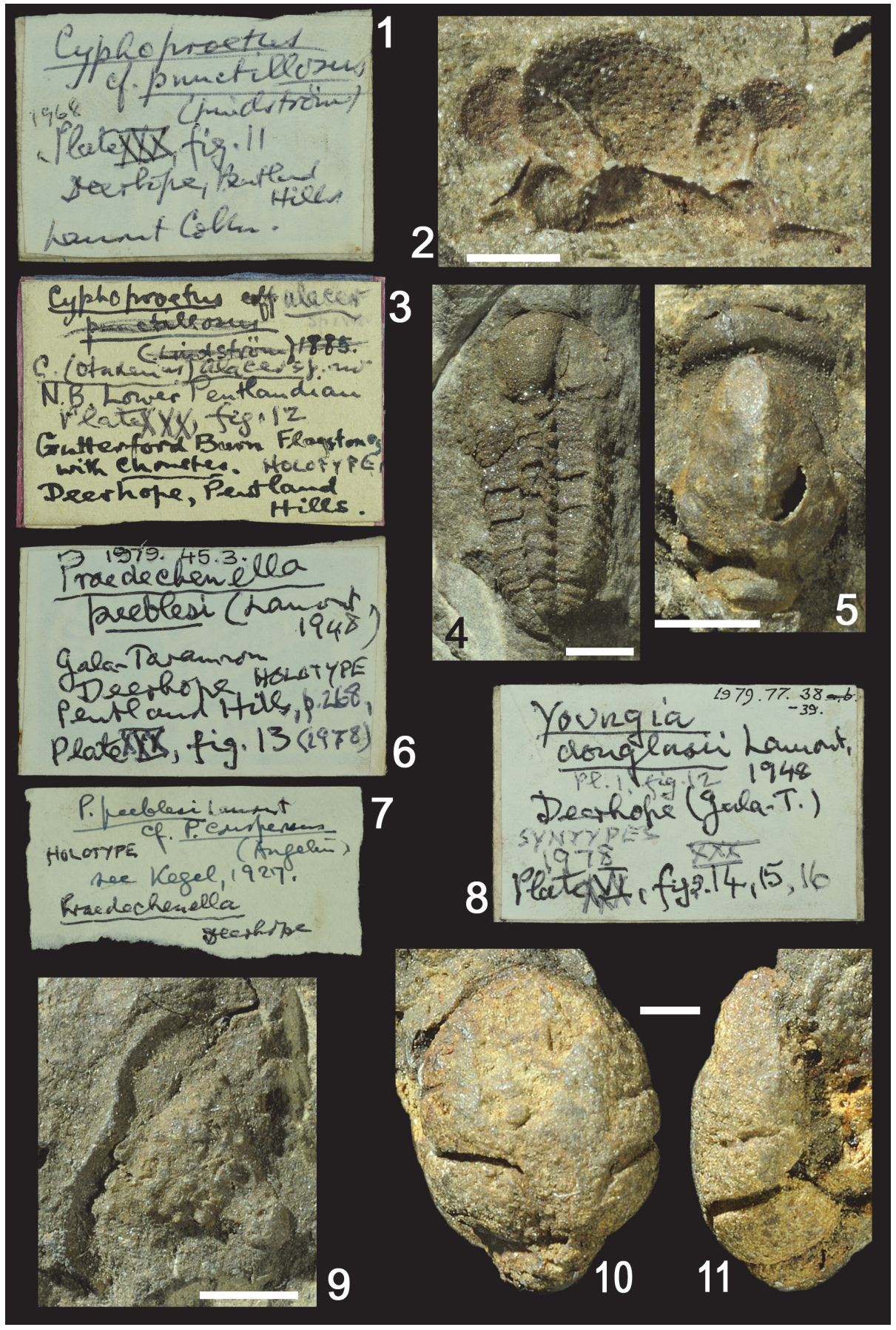

FIGURE 17. 1, 2: Cyphoproetus cf. punctillosus (Lindström, 1885) from the Deerhope Burn; 1: handwritten label with publication details; 2: specimen NMS G.1979.77.32, figured by Lamont on plate XXX, figure 11. 3, 4: Cyphoproetus (Otademus) alacer Lamont, 1978, from the Deerhope Burn, Deerhope Coral Beds, Deerhope Formation; 3: handwritten label with horizon noted as "Gutterford Burn Flagstones with Chonetes", and age noted as Lamont's "Lower Pentlandian"; 4: specimen NMS G.1979.77.33 from the Lamont Collection, figured by Lamont on plate XXX, figure 12. 57: Praedechenella peeblesi (Lamont, 1948) from the Deerhope Burn, possibly Wether Law Linn Formation; 5: specimen NMS G.1979.45.3, figured by Lamont on plate XXX, figure 13; 6, 7: handwritten labels with details related to the specimen. 8-11: Youngia douglasii (Lamont, 1948) from the Deerhope Burn, possibly the lower part of the Wether Law Linn Formation; 10, 11: dorsal and side views of specimen NMS G.1979.77.38 from the Lamont Collection, figured by Lamont on plate XXX, figures 14 and 16; 8: handwritten label with information on the specimens; 9: specimen NMS G.1979.77.39 from the Lamont Collection, figured by Lamont on plate XXX, figure 15. Scale bars: $2 \mathrm{~mm}$ (figures 4, 5, 9); $1 \mathrm{~mm}$ (figures 2, 10, 11). 
Plate XXX, figure 13; page 268

Praedechenella peeblesi (Lamont, 1948)

Figure 17.5-7

NMS G.1979.45.3: locality as "Deerhope, Pentland Hills" and, therefore, probably Deerhope Burn; horizon unknown, but possibly Wether Law Linn Formation. According to Morris (1988), horizon and locality as Wether Law Linn Formation, Deerhope Burn, Grid Ref. NT 145582 approximately, which may be locality R255.

The species was reassigned to Proetus (Lacunoporaspis) sp. by Clarkson and Howells (1981, p. 510). The species name should be suppressed as nomen nudum according to Clarkson and Howells (1981).

Specimen figured by Clarkson and Howells (1981), on plate 77 , figure 4 .

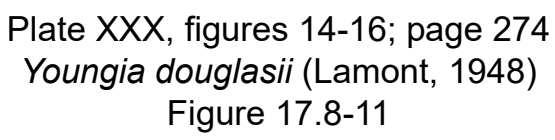

NMS G.1979.77.38, and NMS G.1979.77.39: locality as "Deerhope", probably Deerhope Burn; no horizon, but Clarkson and Howells (1981) suggested the species was collected from the lower part of the Wether Law Linn Formation. Grid Ref. NT 14525815 quoted by Morris (1988), this may possibly be locality R 255 .

Clarkson and Howells (1981, p. 518) regarded the taxonomic identification as valid. However, Lamont (1948) did not provide any description of his species and, therefore, failed to conform to Article 13 of the ICZN. Subsequently, Lamont (1978) proposed a succinct comparison of the species with other coeval species from Gotland. As stated in the ICZN (Article 50.1 - Identity of authors) "The author of a name or nomenclatural act is the person who first publishes it [Arts. 8, 11] in a way that satisfies the criteria of availability [Arts. 10 to 20]." Clarkson and Howells (1981) are the first authors to provide a diagnosis, full description and adequate illustration of the species. Authorship should therefore refer to Clarkson and Howells (1981).

Morris (1988) refers this species to Hyrokybe Lane, 1972.

NMS G.1979.77.38: figured by Lamont (1948), on plate 1, figure 12; figured by Clarkson and Howells (1981), on plate 80, figure 11.

Plate XXX, figures 17, 18; page 275

Hemiarges hendersoni (Lamont, 1948)

Figure 18.1-2

NMS G.1979.45.2: locality as "Deerhope", probably Deerhope Burn; no horizon, but possibly the upper part of the Deerhope Formation.
This species was re-assigned to Hemiarges rolfei Lamont, 1965, by Clarkson and Howells (1981, p. 532), whereas Morris (1988) regarded Hemiarges hendersoni as valid.

The species name is regarded here as valid as Lamont provided a succinct description that conforms to Article 13 of the ICZN.

Figured by Clarkson and Howells (1981), plate 79 , figure 13 , as Hemiarges rolfei.

A specimen of this species was figured by Lamont (1948), as Lichas hendersoni on plate 1, figure 11. It is not clear whether it is the same specimen.

Plate XXX, figures 19, 20; page 275

Bruxaspis dealgach (Lamont, 1978)

Figure 18.3-5

NMS G.1979.77.45.1 and NMS G.1979.77.45.2: locality probably Deerhope Burn; no horizon.

The species was re-assigned to Anacaenaspis dealgach (Lamont, 1978) by Clarkson and Howells (1981, p. 529).

The species name proposed by Lamont (1948) was regarded as nomen nudum by Clarkson and Howells (1981), but Lamont (1978) subsequently provided a diagnosis, and the name is therefore accepted as valid.

Clarkson and Howells (1981) compared Lamont's material to specimens collected by J.C. Tipper, deposited in the National Museums Scotland collection, originating from the lower part of the Wether Law Linn Formation, at locality R263 to R265 along the Wether Law Linn.

Morris (1988) synonymised this species with Anacaenaspis pectinata (Angelin, 1854).

Figured by Lamont (1948), figures 8 , 9, as Acidaspis dealgach.

Figured by Clarkson and Howells (1981), plate 81, figure 2, G.1979.77.45.1 only and misquoted as NMS G.1979.77.452.

Plate XXX, figure 21; page 276

Dudleyaspis lothiana (Lamont, 1948)

Figure 18.6

Topotype GSE 13487 is in the BGS collection: locality as Bavelaw Inlier, possibly the only known locality, a small quarry near Bavelaw Castle. Lamont's illustration is a drawing of the latex cast of the original specimen, which is held in the NMS Palaeobiology collection.

The species was re-assigned to Leonaspis lothiana (Lamont, 1948) by Clarkson and Howells (1981, p. 527) [confirmed by Howells, 1982, and Morris, 1988]. The species name proposed by Lamont (1948) cannot be regarded as valid as it 


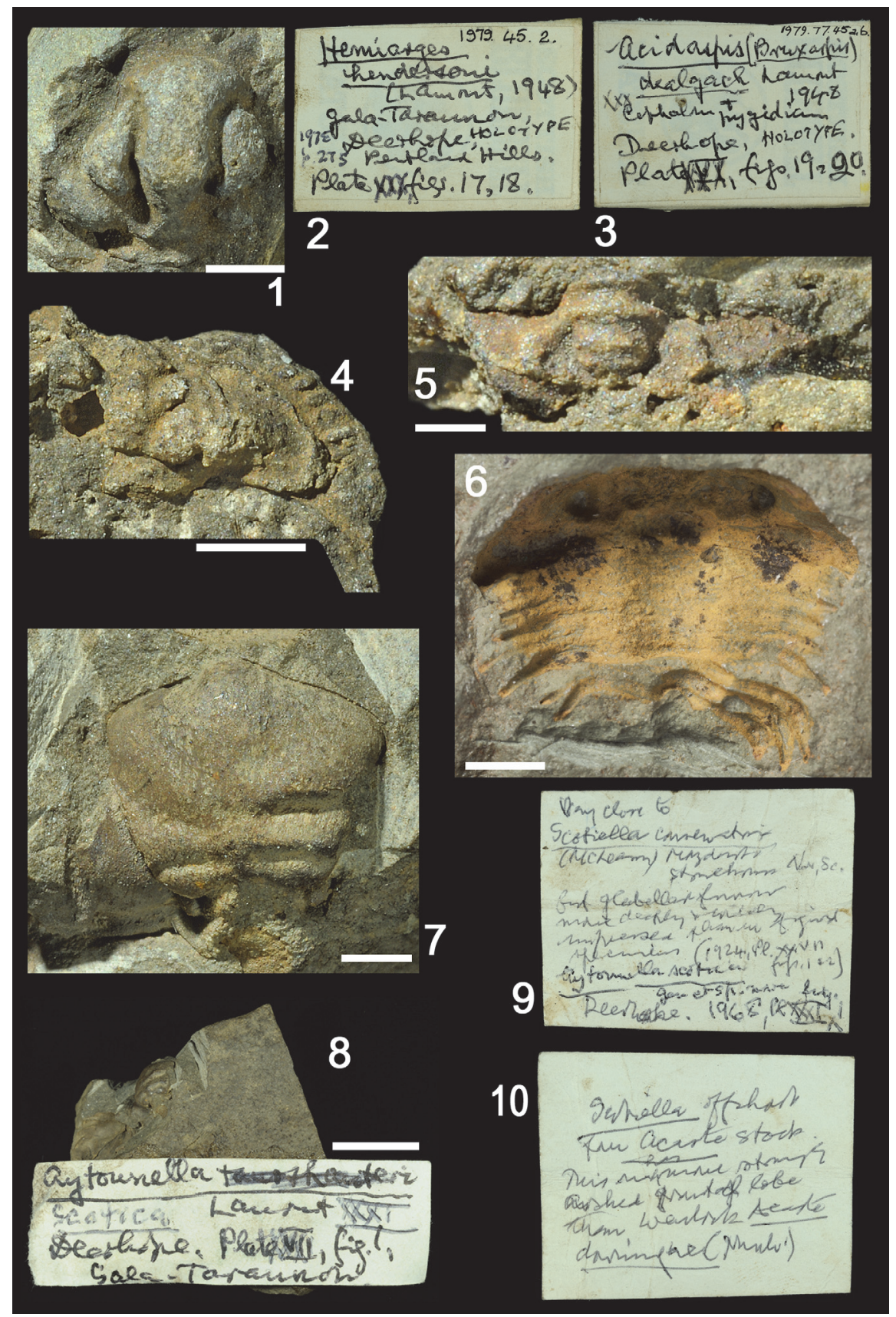

FIGURE 18. 1, 2: Hemiarges hendersoni (Lamont, 1948) from the Deerhope Burn, possibly the upper part of the Deerhope Formation; 1: specimen NMS G.1979.45.2, figured by Lamont on plate XXX, figures 17, 18; 2: handwritten label with information on the specimen. 3-5: Bruxaspis dealgach (Lamont, 1978) from the Deerhope Burn; 3: handwritten label with information on the specimens; 4, 5: specimen NMS G.1979.77.45.2 (cephalon, (4)) and specimen NMS G.1979.77.45.1 (pygidium (5)) from the Lamont Collection, figured by Lamont on plate XXX, figures 19 and 20. 6: Dudleyaspis lothiana (Lamont, 1948) from the Bavelaw Inlier, possibly from a small quarry near Bavelaw Castle, horizon unspecified; specimen from the British Geological Survey collection GSE14487, a latex cast is reproduced by Lamont on plate XXX, fig. 21. Image BGS (C) UKRI 2018 reproduced with the kind permission of the British Geological Survey, Photo P835160 from GB3D Website, http://www.3d-fossils.ac.uk/tou.html, released under a Creative Commons Attribution-NonCommercial-ShareAlike 3.0 Unported License (http://creativecommons.org/licences/by-nc-sa/3.0/). 7-10: Aytounella scotica Lamont, 1978, from the Deerhope Burn, Wether Law Lin Formation; specimen NMS G.1979.77.37, external mould of the glabella (7) as figured on plate XXXI, figure 1, and view of the handwritten label (8) glued onto the sample; 9, 10: handwritten label (recto and verso) discussing the affinity of the species. Scale bars: $10 \mathrm{~mm}$ (figure 8); $2 \mathrm{~mm}$ (figures 1, 4, 6); $1 \mathrm{~mm}$ (figures 5, 7). 
fails to conform to Article 13 of the ICZN (no description). However, Lamont (1978) proposed a short description and comparison of the species with other taxa. The authorship for this species should therefore be Lamont (1978).

Plate XXXI, figure 1; page 269

Aytounella scotica Lamont, 1978

Figure 18.7-10

NMS 1979.77.37: locality as Deerhope burn; Wether Law Linn Formation.

Lamont provided a diagnosis and comparison of this new taxon and, therefore, the binomial can be regarded as valid. This genus is regarded as valid by Morris (1988) and is listed as available according to Jell and Adrain (2002).

Lamont compared very closely the species from the Pentland Hills with Scotiella conservatrix (McLearn, 1924) from the Moydart and Stonehouse formations (Ludlow to Lochkovian) of Nova Scotia, but differentiated the latter by a "first glabellar furrow more deeply markedly impressed than in figured specimens" in McLearn (1924, plate XXVII, figures 1, 2) (see Figure 18.9). Shergold (1967) emended the species conservatrix stating that it possesses "three well defined pairs of lateral glabellar furrows" (page 6). The present specimen is characterised by a deep anterior glabellar furrow (S3) subparallel to the median glabellar furrow (S2) and of equal depth, whereas the posterior glabellar furrow (S1) seems deeper than S2 and S3, although the present specimen is not well preserved. Lamont also regarded Scotiella as an "offshoot from Acaste stock" (see Figure 18.10), but Ramsköld and Edgecombe (1993) considered that some European species of Scotiella were not very different from Acastella. Acaste is characterised by "S1 deeper than S2 and S3; S3 oblique, curving only slightly downwards at distal end" (Storey, 2012).

Acastella is characterised by glabellar furrows as follows: "S1 deep, subparallel to S2, equally wide, and of similar depth; S3 narrower than S1 and S2, curving markedly downwards at distal end terminating close to S2" (Storey, 2012, p. 171). Moreover, Lamont characterised his specimen having a "more strongly arched frontal lobe than Wenlock Acaste downingiae (Murch.)" (see Figure 18.10). Although the Scottish specimen seems similar to Acaste based on the glabellar furrow, affinities of the specimen are not clearly defined due to the paucity of material.

Incidentally, Lamont originally named his new species Aytounella tamoshanteri (see scored label attached to the specimen on Figure 18.8), after the eponymous Robert Burns' poem and character.

\author{
Plate XXXI, figure 2; page 269 \\ Acernaspis (Eskaspis) sufferta \\ (Lamont, 1948) var. ? \\ Figure 19.1-2
}

NMS G.1979.77.35: locality as possibly Deerhope Burn; horizon as lower part of the Wether Law Linn Formation (Clarkson et al., 1977, p. 126).

The subgenus Eskaspis is regarded by Howells (1982) as a junior subjective synonym of Acernaspis. Lamont (1978) differentiated this specimen as a narrower and more elongate form of $A$. (E.) sufferta. However, Lamont never named his subspecies, and marked it with a question mark. Moreover, in the figure caption he mentioned this specimen as possibly a new species, identifying the present specimen as $A$. (E.) cf. sufferta. On the other hand, Lamont (1948) did not provide any description for $A$. (E.) sufferta, but later, Clarkson et al. (1977) provided a thorough diagnosis, description and illustration of this species. The species should have been regarded as nomen nudum by Clarkson et al. (1977) as it failed to conform to Article 13 of the ICZN; nevertheless, following these authors work it can be regarded as valid and should be identified as $A$. (E.) sufferta Clarkson et al., 1977, as per Article 50 of the ICZN. Therefore, the specimen can be identified as Acernaspis (Eskaspis) sufferta Clarkson et al., 1977 subsp. nov. Lamont, 1978.

Plate XXXI, figures 3, 4; page 269

Acernaspis (Eskaspis) phylax Lamont, 1978

Figure 19.3-4

NMS G.1979.77.36.1: locality as "Side of Wether Law Linn", lower part of the Wether Law Linn Formation.

Morris (1988) did not recognise the validity of the subgenus name and listed it as Acernaspis phylax Lamont.

Although Lamont did not provide a description of his new species, it was recognised as valid according to Ramsköld and Werdelin (1991).

Plate XXXI, figure 5; page 270

Calgachia calgach (Lamont, 1948)

Specimen is not traced. Locality possibly along the Wether Law Linn, Wether Law Linn Formation.

The drawing of the specimen in Lamont (1978) is not a drawing of the specimen figured in Lamont (1948). The latter specimen was probably reproduced, as a drawing, in Craig and Duff (1976, 

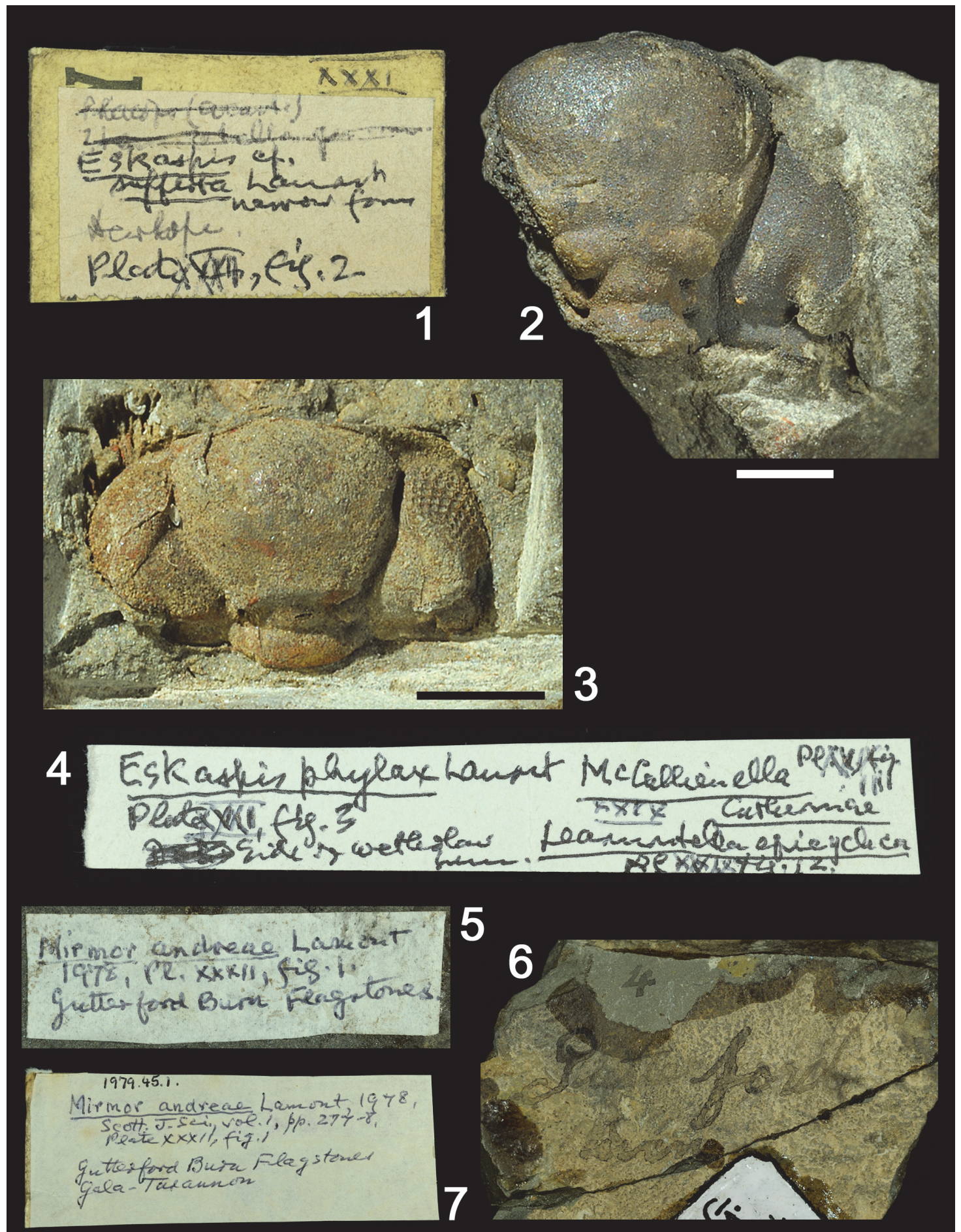

FIGURE 19. 1, 2: Acernaspis (Eskaspis) cf. sufferta (Lamont, 1948) from the Deerhope Burn, lower part of the Wether Law Linn Formation; 1: handwritten label with information on the specimen; 2: part of cephalon of specimen NMS G.1979.77.35 from the Lamont Collection, figured by Lamont on plate XXXI, figure 2. 3, 4: Acernaspis (Eskaspis) phylax Lamont, 1978, from the Wether Law Linn, Wether Law Linn Formation; 3: specimen NMS G.1979.77.36.1 from the Lamont Collection, figured by Lamont on plate XXXI, figures 3, 4; 4: handwritten label describing the specimen, with information for other specimens. 5-7: Mirmor andreae Lamont, 1978, from the Gutterford Burn, lowest Deerhope Formation; 5, 7: handwritten labels with information on the specimen; 6: handwritten label with a note of the locality "Gutterford Burn", on the reverse of specimen NMS G.2001.100.4. Scale bars: $2.5 \mathrm{~mm}$ (figure 3); $2 \mathrm{~mm}$ (figure 2). 
p. 19), but there is no mention there of the identity or origin of the specimen.

Strusz (1980) put in synonymy with Encrinurus many taxa Lamont $(1965,1978)$ erected as new genera, i.e., Calgachia, Paracalgachia, Aristobeggia, Leitchia and Trippia. He argued that the relation between these monotypic genera and previously described species will remain uncertain until more and better material is collected and described. Strusz (1980) regarded Calgachia calgach and Paracalgachia henshawensis as conspecific, pending more material described.

Strusz (1980, p. 53) regarded this species as belonging to the Encrinurus variolaris plexus, although he believed the species was insufficiently known to be confident.

Clarkson and Howells (1981, p. 519) reassigned the species to Encrinurus expansus Haswell, 1865, and regarded the name as nomen nudum (it fails to conform to Article 13 of the ICZN).

Plate XXXI, figure 6; page 271

Paracalgachia henshawensis (Lamont, 1978)

Specimen not traced: locality as Henshaw Burn by Lamont, but Clarkson and Howells (1981) noted that the specimens originated from locality R98 on the west bank of the Henshaw Burn; upper part of the Wether Law Linn Formation.

Strusz (1980) considered the genus name, Paracalgachia Lamont, 1965, as nomen nudum, re-assigned the binomial to Encrinurus, and regarded it as a "possible synonym of $E$. calgach" (p. 55), pending more material was studied.

Clarkson and Howells (1981, p. 522) put this species in synonymy with Encrinurus pagei (Haswell, 1865) [this was followed by Morris 1988], and also regarded Paracalgachia as nomen nudum.

Plate XXXI, figure 7; page 271

Wallacia expansa (Haswell, 1865)

Specimen not traced: locality as Henshaw Burn and, more precisely, as R98 according to Clarkson and Howells (1981); upper part of the Wether Law Linn Formation.

Strusz (1980) regarded Wallacia as very close to the genus Encrinuroides Reed, 1931.

This species was put in synonymy with Encrinurus pagei by Clarkson and Howells (1981, p. 522) [this is followed by Morris, 1988].

Howells (1982) considered this genus a junior subjective synonym of Encrinurus. However, she agreed with the synonymy list put in place by Clarkson and Howells (1981) as far as Lamont's (1978) specimen was concerned. The specimens of Wallacia expansa mentioned by Strusz (1980) were re-assigned to Encrinurus expansus by Howells (1982).

The genus name was regarded valid by Ramsköld and Edgecombe (1994), but these authors agreed on Clarkson and Howells' (1981) conclusions.

Plate XXXI, figure 8; page 271

Aristobeggia bargainiensis Lamont, 1978

Specimen not traced: locality as Bargany Pond Burn, near Dailly, Ayrshire; Woodburn Formation (Telychian). This horizon is equivalent to the Reservoir Formation in the Pentland Hills.

Lamont (1978) misspelled the species name as bargainienses in his plate explanation.

Aristobeggia is synonymised with Encrinurus by Strusz (1980, p. 17), who regarded the genus as nomen nudum.

Clarkson and Howells (1981) and Howells (1982) regarded this name as invalid. Nevertheless, Howells (1982) assigned this genus to $E$. mullochensis. Morris (1988) synonymised it with $E$. (Trippia) mullochensis. Jell and Adrain (2002, p. 344) give Aristobeggia as a valid name as Lamont's (1978) diagnosis fulfils Article 13 of the ICZN.

Three species are already described from the same locality: E. mullochensis Reed, 1931, E. stateratus Howells, 1982 and Encrinurus cf. E. squarrosus Howells, 1982, but without any specimen and only a line drawing, an assessment of the taxonomic name erected by Lamont is difficult to propose. The name is regarded as nomen dubium because the type is missing.

Plate XXXI, figure 9; page 272

Leitchia knockgairdnerensis (Lamont, 1965)

Specimen not traced: locality as Knockgardner farm, Carrick, Ayrshire; Knockgardner Formation (Early Wenlock).

Lamont (1965) spelled this species name as knockgardnerensis instead of knockgairdnerensis (Lamont, 1978, p. 272). However, originally there was no description of the new species and therefore fails to conform to Article 13 of the ICZN. The name was regarded as nomen nudum by Morris (1988), who synonymised both Leitchia knockgairdnerensis and Brycewylia mira with Encrinurus knockgairdnerensis (Lamont, 1978).

Strusz (1980) regarded the genus name as nomen nudum and re-assigned the species to Encrinurus (p. 17).

This species is regarded as synonym of Encrinurus hagshawensis Lamont, 1965, by Howells (1982) (see also Ramsköld and Edgecombe, 1994). 
Ramsköld and Edgecombe (1994, p. 90) regarded Leitchia as a possible junior subjective synonym of Wallacia.

The genus name is listed as available by Jell and Adrain (2002, p. 344).

Plate XXXI, figure 10

Brycewylia mira Lamont, 1978

Specimen not traced: locality as Knockgardner farm, Carrick, Ayrshire; Knockgardner Formation (Early Wenlock).

There is no description of the taxon in Lamont's paper.

The genus name was regarded as numen nudum by Howells (1982) and synonymised the species with Encrinurus hagshawensis Lamont, 1965 (type for MacGuiganella Lamont, 1978); see also Ramsköld and Edgecombe (1994, p. 91).

Plate XXXI, figures 11, 12; page 273

MacGuiganella hagshawensis (Lamont, 1965)

Specimen BU 1899 (listed as Rolfe Colln 40 by Lamont, 1965) deposited in the collections of the Lapworth Museum, University of Birmingham: locality as Hagshaw Hills, Strathclyde, near Parish Holm, Monks Water [NS 7787 2919]; Ree Burn Formation (Telychian; equivalent to the Wether Law Linn Formation). This specimen is figured on plate XXI, fig. 12 .

Strusz (1980) re-assigned the species to Encrinurus. Howells (1982) regarded the binomial name as a synonym of Encrinurus hagshawensis Lamont, 1965, and rejected MacGuiganella as invalid.

Ramsköld and Edgecombe (1994, p. 90) regarded the genus as a junior subjective synonym of Wallacia.

Specimen BU 1899: figured by Lamont (1965) on plate 5 , figure 4; figured by Howells (1982) on plate 9 , fig. 9 .

Plate XXXI, figures 13, 14; page 273

Curriella newlandensis Lamont, 1978

Lectotype and paralectotype are deposited as HM A22641 and HM A22642, respectively (see Edgecombe and Chatterton, 1990b), in the collections of the Hunterian Museum, Glasgow; locality quoted as "150 m east of Newlands Farm, Craighead Inlier, near Girvan, Scotland"; Newlands Formation (lower Aeronian).

Strusz (1980, p. 9) regarded Curriella as tentatively assigned to the genus Encrinuroides Reed, 1931, noting that C. newlandensis recalls Encrinuroides sexcostatus Phillips and Salter. The species was re-assigned by Howells (1982) to
Encrinurus? newlandensis (followed by Morris, 1988). Edgecombe and Chatterton (1990b) considered that the name was valid and regarded Curriella newlandensis Lamont as the type species for the genus Curriella.

Lectotype cranidium and paralectotype librigena figured by Edgecombe and Chatterton (1990b), on plate 1, figures 2, 3, 5, 9.

Plate XXXI, figure 15; page 274

Curriella (Saoria?) prisca Lamont, 1978

Holotype is deposited as HM A22643 in the collections of the Hunterian Museum in Glasgow: locality as for Curriella newlandensis, "150 m east of Newlands Farm, Craighead Inlier, near Girvan, Scotland"; Newlands Formation (lower Aeronian).

According to Strusz (1980, p. 9), Curriella (Saoria?) is no different from Curriella.

Howells (1982) re-assigned the species to Encrinurus? newlandensis (followed by Morris, 1988). Edgecombe and Chatterton (1990b) regarded the subgenus as doubtful.

Edgecombe and Chatterton (1990b) figured the holotype on plate 1 , figure 10 , but re-assigned the species to Encrinurus priscus.

Plate XXXI, figure 16; page 272

Trippia penkillensis Lamont, 1978

Specimen not traced: locality as Ramson Gorge, Penkill, Girvan; horizon possibly Woodburn Formation (Telychian; it is equivalent to the Reservoir Formation in the Pentland Hills).

The species was re-assigned to Encrinurus by Strusz (1980, p. 17).

Howell (1982) synonymised this species (and Aristobeggia bargainiensis) with Encrinurus mullochensis Reed, 1931, and therefore did not accept the validity of Lamont's genus.

Morris (1988) synonymised Nucleurus and Aristobeggia with Trippia (based on Howells 1982, which he regarded as a subgenus of Encrinurus).

Edgecombe and Chatterton (1990a) seemed to favour Howell's conclusions, pending Lamont's types are identified.

Plate XXXI, figures 17, 18; page 277

Craspedobolbina rennieana Lamont, 1978

Specimen not traced: locality as Wether Law Linn; horizon as Wether Law Linn Formation.

Lamont described this species from an undefined outcrop in the upper part of the Wether Law Linn Formation. Craspedobolbina (Mitrobeyrichia) impendens (Haswell) is known from lower horizons in the same formation (R260, along the Deerhope Burn; R263 and R265, along the Wether Law Linn; 


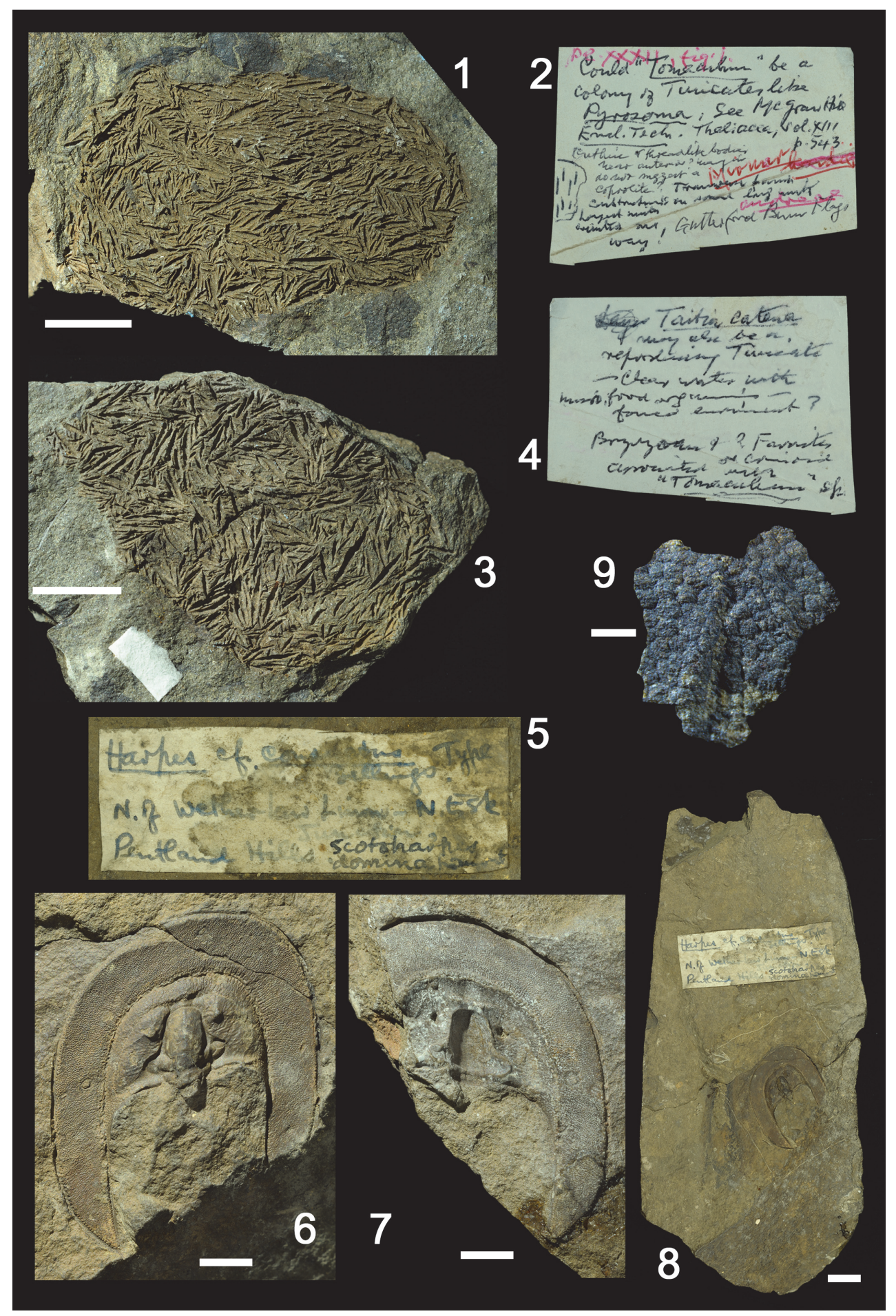

FIGURE 20. 1-4: Mirmor andreae Lamont, 1978, from the Gutterford Burn, lowest Deerhope Formation; specimen NMS G.1979.45.1, original external mould (1), the latex cast of this specimen is figured by Lamont on plate XXXII, figure 1, and counterpart (3) registered as NMS G.2001.100.4; 2, 4: handwritten labels with information on the specimen. 5-8: Scotoharpes domina Lamont, 1948, from the Henshaw Burn (possibly R98), Wether Law Linn Formation; 5, 8: close-up of handwritten label (5) glued on specimen NMS G.1978.61.547 (image 8), which was not figured in Lamont (1978); 6, 7: close-up of cephalon (part and counterpart). 9: Taitia catena Crookall, 1930, from the Gutterford Burn, lowest Deerhope Formation; specimen NMS G.1979.45.1, near bottom right of Mirmor andraea on Figure 20.1; Figures 20.2 and 20.4 relate also to this species. Scale bars: $10 \mathrm{~mm}$ (figures 1, 3, 8); $5 \mathrm{~mm}$ (figures 6, 7); $2 \mathrm{~mm}$ (figure 9). 
R82 and R101, along the North Esk River). Although only a brief description of the species and poor illustrations are provided the name should be considered as valid, until Lamont's specimens are recovered or more specimens are collected from similar horizons, as it conforms to article 13 of the ICZN code.

Plate XXXII, figure 1; page 277

Mirmor andreae Lamont, 1978

Figure 19.5-7; Figure 20.1-4

This species was illustrated on plate 32 with the four brachiopod species described in the following section "Length to breadth proportions in brachiopod palaeoecology." It is illustrated there by a cast of the holotype NMS G.1979.45.1.

Lamont (1978) described this fossil as part of the amour of an ostracoderm fish, but also suggested other possible affinities (page 278). Bengston (1981) reviewed the holotype (a cast sent to him directly by Lamont), concluded it was an alcyonacean octocoral (soft corals), and assigned Lamont's species to Atractosella Hinde.

Figured by Bengston (1981) on text-figure 8 (p. 288).

Figured by Stewart et al. (2007) on plate 37, figure 1.

\section{TAXA NOT FIGURED BY LAMONT}

Haswellia macrothalma (Haswell, 1865); described on page 250.

Lamont did not provide any indication of locality or horizon. Haswell (1865) mentioned the species macrothalma from his locality I, but did not describe the specimen he figured on plate I, figure 13.

Scotoharpes domina Lamont, 1948; described on page 265

Figure 20.5-8

NMS G.1978.61.547: Henshaw Burn, Grid Ref. NT 14825885 , according to Morris (1988); this locality is very likely $R$ 98; Wether Law Linn Formation.

The validity of the genus was accepted by Norford (1973), who provided a full description of the species, and confirmed that Aristoharpes Whittington, 1950, is a junior subjective synonym of Scotoharpes. Clarkson and Howells (1981) provided some additional details. Although not recorded in any publications, the specimen's registration number is NMS G.1978.61.547. Norford's study was based on a plaster replica of the plasticine mould of Lamont's original specimens made by Lamont himself.

\section{Encrinurus (Frammia) pagei (Haswell, 1865); described on page 270}

Lamont (1948, pl. 1, fig. 19) figured a specimen of Cromus pagei (Haswell). However, this specimen looks very different from Encrinurus pagei (Haswell) described by Clarkson and Taylor (2007b, plate 21, figures 9, 11) from the Upper Member of the Wether Law Linn Formation (locality R92).

Calymene carlops Lamont, 1949; described in Lamont, 1978, p. 274

Horizon as lower part of the Wether Law Linn Formation: the specimens described by Lamont (1949) were collected from the Deerhope Burn and "high on the south-west side of the Wetherlaw Linn" (p. 323)

The new species was erected by Lamont (1949) even though a specimen of this species was figured by Lamont (1948), but no description or comparison with other taxa was undertaken. The correct date of availability for the species is 1949 when conditions were met to make the name available (conforming to Articles 10 and 13 of the ICZN). The specimen figured by Lamont (1948, plate 1 , figure 13) is the same specimen as figured by Lamont (1949, plate 18, figure 13). It is one of the syntypes erected by Lamont (1949) and referenced as Lamont Coll. No. 34 (internal mould of a cranidium); the second syntype is an internal mould of a pygidium (Lamont Coll. No. 35; plate 18 , figure 17 ).

It was reassigned to Calymene frontosa Lindström, 1885, by Clarkson and Howells (1981, p. 523).

This was synonymised with Calymene (s.l.) frontosa Lindström by Morris (1988). This species is present in the NEI in the Lower Member of the Wether Law Linn Formation (localities R260, R263 and R265), and rare in the Upper Member (locality R92) and in the Deerhope Coral Beds (R247) (Clarkson and Taylor, 2007b).

Taitia catena Crookall, 1930; described on page 279

Figure 20.9; see also Figure 20.2, 4 for labels NMS G. 1979.45.1: the locality, although not clearly cited by Lamont, may be the "Gutterford Burn flags", which corresponds to the lower part of the Deerhope Formation (possibly localities R189 to R195).

The specimen figured here (Figure 20.9) is possibly the specimen described by Lamont, but in the absence of an illustration, this is putative. The label figured on Figures 20.2 and 20.4 (recto and 
verso) mentions both Mirmor and Taitia, which indicates that both specimens may be on the same sample (here NMS G. 1979.45.1). Lamont speculated on the possible affinity of Taitia catena (see page 279) and thought it could represent the "reproductive bodies" of a Tunicate (Figure 20.4).

This taxon was tentatively assigned to the Plantae by Crookall (1930) and does not resemble the specimen shown here. We suspect Lamont to be mistaken.

The structure figured here shows the characteristic reticulate scuplture of Dictyocaris alga (see for example Botting (2007), text-fig. 4.2B). Dictyocaris ramsayi Salter, 1860 is recorded from the NEI in the lower part of the Deerhope Formation, but also from the Lower Silurian of Lesmahagow (30 $\mathrm{km}$ SE of Glasgow). This species is characterised by "a variable ornament of irregular polygonal embossing, sometimes with polygons $(1-2 \mathrm{~mm}$ across) combining to form meandering channels" (Botting 2007, p. 39), which is present in the present specimen. Therefore, Lamont's specimen is here identified as Dictyocaris ramsayi Salter.

\section{ACKNOWLEDGEMENTS}

The authors would like to thank S. Donovan and $\mathrm{J}$. Botting for their thorough and constructive reviews that greatly improved the quality of this paper. E. Callaghan and P. Shepherd (British Geological Survey, Edinburgh and Keyworth) are thanked for the loan of material. The image used to illustrate Dudleyaspis lothiana is reproduced with the kind permission of the British Geological Survey (for full credit see caption of Figure 18.6). The authors thank Matus Hyzny and Jennifer Pattison Rumford for their careful editing of the article.

\section{REFERENCES}

Anderson, L.I., Clarkson, E.N.K., Stewart, S.E., and Mitchell, D. 2007. An Upper Llandovery Konservat-Lagerstätte in a depositional context: the Pentland Hills Eurypterid Bed, Midlothian. Scottish Journal of Geology, 43:41-50. https://doi.org/10.1144/sjg43010041

Angelin, N.P. 1854. Palaeontologia Scandinavica. T.O. Weigel, Lipsiae.

Austin, T. and Austin, T. 1843-1849. Monograph on Recent and Fossils Crinoidea. London, Bristol.

Barrande, J. 1846. Notice Préliminaire sur le Système Silurien et les Trilobites de Bohême. C.L. Hirschfeld, Leipzig.

Baumiller, T.K. 2003. Evaluating the interaction between platyceratid gastropods and crinoids: a cost-benefit approach. Palaeogeography, Palaeoclimatology, Palaeoecology, 201:199-209. https://doi.org/10.1016/S0031-0182(03)00625-4

Bengston, S. 1981. Atractosella, a Silurian alcyonacean octocoral. Journal of Paleontology, 55(2):281-294.

Botting, J.P. 2007. Algae, receptaculitids and sponges, p. 36-49. In Clarkson, E.N.K., Harper, D.A.T., Taylor, C.M., and Anderson, L.I. (eds.), Silurian Fossils of the Pentland Hills, Scotland. Palaeontological Association Field Guides to Fossils: number 11. The Palaeontological Association, London.

Bouchet, P., McLean, J.H., and Waren, A. 1983. Monoplacophorans in the North Atlantic. Oceanologica Acta, 6(2):117-118.

Bouchet, P. and Rocroi, J.-P. 2005. Classification and nomenclator of gastropod families. Malacologia, 47(1-2):1-397.

Bowsher, A.L. 1955. Origin and adaptation of platyceratid gastropods. University of Kansas Paleontological Contributions, Mollusca, Article 5:1-11, pls 1-2.

Brown, D.J. and Henderson, J. 1868. On the Silurian rocks of the Pentland Hills. Transactions of the Edinburgh Geological Society, 1(1):23-33. https://doi.org/10.1144/transed.1.1.23

Candela, Y. and Crighton, W.R.B. 2015. Revision of Plumulites ruskini Lamont, and new data from the Silurian of the Pentland Hills, Scotland. Scottish Journal of Geology, 51(1):31-42. https://doi.org/10.1144/sjg2014-053

Candela, Y. and Crighton, W.R.B. 2017. Addenda to the record of machaeridian shell plates in the Wether Law Linn Formation (Late Llandovery), Pentland Hills, Scotland. Scottish Journal of Geology, 53(1):35-39. https://doi.org/10.1144/sjg2016-006 
Cifelli, R.L. and Kielan-Jaworowska, Z. 2005. Diagnosis: differing interpretations of the ICZN. Acta Palaeontologica Polonica, 50(3):650-652.

Clarke, J.M. and Ruedemann, R. 1903. Guelph fauna in the state of New York. New York State Museum Memoirs, 5:1-100.

Clarkson, E.N.K. 2000. Pentland Odyssey. Scottish Journal of Geology, 36(1):8-16. https:// doi.org/10.1144/sjg36010008

Clarkson, E.N.K. 2007. Archie Lamont (1907-1985), geologist and poet. Proceedings of the Geological Society of Glasgow, 150th Anniversary Special Edition, session 150:36-39.

Clarkson, E.N.K., Eldredge, N., and Henry, J.-L. 1977. Some Phacopina (Trilobita) from the Silurian of Scotland. Palaeontology, 20(1):119-142, pls 18-20.

Clarkson, E.N.K., Harper, D.A.T., and Peel, J.S. 1995. Taxonomy and palaeoecology of the mollusc Pterotheca from the Ordovician and Silurian of Scotland. Lethaia, 28(2):101-114. https://doi.org/10.1111/j.1502-3931.1995.tb01600.x

Clarkson, E.N.K. and Howells, Y. 1981. Upper Llandovery trilobites from the Pentland Hills, Scotland. Palaeontology, 24(3):507-536.

Clarkson, E.N.K. and Taylor, C.M. 2007a. Silurian rocks and fossils in the Pentland Hills, p. 8-29. In Clarkson, E.N.K., Harper, D.A.T., Taylor, C.M., and Anderson, L.I. (eds.), Silurian Fossils of the Pentland Hills, Scotland. Palaeontological Association Field Guides to Fossils: number 11. The Palaeontological Association, London.

Clarkson, E.N.K. and Taylor, C.M. 2007b. Trilobites, p. 123-132. In Clarkson, E.N.K., Harper, D.A.T., Taylor, C.M., and Anderson, L.I. (eds.), Silurian Fossils of the Pentland Hills, Scotland. Palaeontological Assocation Field Guides to Fossils: number 11. The Palaeontological Association, London.

Craig, G.Y. and Duff, P.M.D. 1976. The Geology of the Lothians and south-east Scotland. An Excursion Guide. Edinburgh Geological Society, Scottish Academic Press, Edinburgh.

Crookall, R. 1930. On some curious fossils from the Downtonian and Lower Old Red Sandstone of Scotland. Proceedings of the Royal Society of Edinburgh, 50:175-178. https://doi.org/ $10.1017 /$ S0370164600044849

Davidson, T. 1868. The Silurian Brachiopoda of the Pentland Hills. Transactions of the Geological Society of Glasgow, 1:1-21.

Donald, J. 1899. Remarks on the genera Ectomaria Koken, and Hormotoma Salter, with descriptions of British species. Quarterly Journal of the Geology Society, London, 55:251272. https://doi.org/10.1144/GSL.JGS.1899.055.01-04.19

Ebbestad, J.O.R. 2007. Gastropods, p. 109-122. In Clarkson, E.N.K., Harper, D.A.T., Taylor, C.M., and Anderson, L.I. (eds.), Silurian Fossils of the Pentland Hills, Scotland. Palaeontological Assocation Field Guides to Fossils: number 11. The Palaeontological Association, London.

Edgecombe, G.D. and Chatterton, B.D.E. 1990a. Mackenziurus, a new genus of the Silurian "Encrinurus" variolaris Plexus (Trilobita). American Museum Novitates, 2968: 22 pp.

Edgecombe, G.D. and Chatterton, B.D.E. 1990b. Systematics of Encrinuroides and Curriella (Trilobita), with a new Early Silurian encrinurine from the MacKenzie Mountains. Canadian Journal of Earth Sciences, 27:820-833. https://doi.org/10.1139/e90-085

Etheridge Jr., R. 1874. Notice of additional species of fossils from the Upper Silurian Series of the Pentland Hills. Transactions of the Edinburgh Geological Society, 2:309-313. https:// doi.org/10.1144/transed.2.3.309

Geldart, E., Clarkson, E.N.K., and Stewart, S.E. 2007. Bivalves, p. 86-99. In Clarkson, E.N.K., Harper, D.A.T., Taylor, C.M., and Anderson, L.I. (eds.), Silurian Fossils of the Pentland Hills, Scotland. Palaeontological Assocation Field Guides to Fossils: number 11. The Palaeontological Association, London.

Goodchild, J.G. 1903. John Henderson. Transactions of the Edinburgh Geological Society, 8(2):165-175. https://doi.org/10.1144/transed.8.2.165

Hall, J. 1847. Paleontology of New York. Volume 1. Albany, printed by C. van Benthuysen.

Haswell, G.C. 1865. On the Silurian formation in the Pentland Hills. Willison, P. Nimmo, Edinburgh.

Holland, C.H. 2000. Silurian cephalopods from the Pentland Hills. Scottish Journal of Geology, 36(2):177-186. https://doi.org/10.1144/sjg36020177

Holland, C.H. 2007. Cephalopds, p. 100-108. In Clarkson, E.N.K., Harper, D.A.T., Taylor, C.M., and Anderson, L.I. (eds.), Silurian Fossils of the Pentland Hills, Scotland. Palaeontological Assocation Field Guides to Fossils: number 11. The Palaeontological Association, London. 
Horný, R.J. 2002. Ordovician Tergomya and isostrophic Gastropoda (Mollusca) of Bohemia: types and referred specimens in the collections of the National Museum, Prague, Czech Republic. Acta Musei Nationalis Pragae, Series B, Natural History, 57:69-102.

Howell, H.H. and Geikie, A. 1861. The Geology of the Neighbourhood of Edinburgh. Map $32-$ Scotland. Memoirs of the Geological Survey of Great Britain and of the Museum of Practical Geology. Longman, Green, Longman and Roberts; London.

Howells, Y. 1982. Scottish Silurian Trilobites. Monographs of the Palaeontographical Society, London:1-76, pls 1-15 (Publ. No. 561, part of Vol. 135 for 1982).

Jell, P.A. and Adrain, J.M. 2002. Available generic names for trilobites. Memoirs of the Queensland Museum, 48(2):331-553.

Lamont, A. 1935. The Drummuck Group: a stratigraphical revision with descriptions of new fossils from the lower part of the Group. Transactions of the Geological Society of Glasgow, 19:288-334. https://doi.org/10.1144/transglas.19.2.288

Lamont, A. 1941. Trinucleidae in Eire. Annals and Magazine of Natural History, series 11, 8:438469. https://doi.org/10.1080/00222934108527221

Lamont, A. 1946. Some Ashgillian and Llandovery gastropods form the Girvan District, Scotland. The Quarry Managers' Journal, 29(12):635-644.

Lamont, A. 1947. Gala-Tarannon Beds in the Pentland Hills, near Edinburgh. Geological Magazine, 84(4):193-208. https://doi.org/10.1017/S0016756800082649

Lamont, A. 1948. Scottish Dragons. The Quarry Managers' Journal, 31(10):531-535.

Lamont, A. 1949. New species of Calymenidae from Scotland and Ireland. Geological Magazine, 86(5):313-323. https://doi.org/10.1017/S0016756800075142

Lamont, A. 1954. New Lamellibranchs from the Gutterford Burn Flagstones (Gala-Tarannon) of the Pentland Hills, near Edinburgh. Proceedings of the Royal Society of Edinburgh, 65(3):271-284. https://doi.org/10.1017/S0080455X00014612

Lamont, A. 1955. Scottish Silurian Chelicerata. Transactions of the Edinburgh Geological Society, 16:200-216. https://doi.org/10.1144/transed.16.2.200

Lamont, A. 1965. Gala-Tarannon trilobites and an ostracod from the Hagshaw Hills, Lanarkshire. Scottish Journal of Science, 1(1):33-46.

Lamont, A. 1978. Pentlandian Miscellany: Mollusca, Trilobita, etc. Scottish Journal of Science, $1(5): 245-302$.

Lane, P.D. 1972. New trilobites from the Silurian of north-east Greenland, with a note on trilobite faunas in pure limestones. Palaeontology, 15:336-364.

Lapworth, C. 1874. Note on the graptolites discovered by Mr John Henderson in the Silurian Shales of Habbie's Howe, Pentland Hills. Transactions of the Edinburgh Geological Society, 2(3):375-377. https://doi.org/10.1144/transed.2.3.375

Lemche, H. and Wingstrand, K.G. 1959. The anatomy of Neopilina galatheae Lemche, 1957. (Mollusca Tryblidiacea). Galatheae Report, 3:9-71.

Lindström, G. 1885. Förteckning på Gotlands Siluriska Crustaceer. Öfversigt of Kongliga Vetenskaps-Akademiens Förhandlingar Stockholm, 6:37-100, pls 12-16.

M'Coy, F. 1851. On some new Silurian Mollusca. Annals and Magazine of Natural History, series 2, 7(1):45-63.

M'Coy, F. 1852. Systematic Descriptions of the British Palaeozoic Fossils in the Geological Museum of the University of Cambridge. John W. Parker and son, London. Deighton, Bell \& Co, and Macmillan \& Co., Cambridge.

McLearn, F.H. 1924. Palaeontology of the Silurian rocks of Arisaig, Nova Scotia. Geological Survey of Canada Memoir, 137:1-180. https://doi.org/10.4095/100857

Molyneux, S.G., Barron, H.F., and Smith, R.A. 2008. Upper Llandovery-Wenlock (Silurian) palynology of the Pentland Hills inliers, Midland Valley of Scotland. Scottish Journal of Geology, 44(2):151-168. https://doi.org/10.1144/sjg44020151

Morris, S.F. 1988. A review of British trilobites, including a synoptic revision of Salter's monograph. Monograph of the Palaeontographical Society, London:1-316 (Publ. No. 574, part of Volume 140 for 1986).

Murchison, R.I. 1839. The Silurian System. John Murray, London.

Norford, B.S. 1973. Lower Silurian species of the trilobite Scotoharpes from Canada and Northern Greenland. Bulletin of the Geological Survey of Canada, 222:9-33, pls 1-4. https:// doi.org/10.4095/102366

Paul, C.R.C. and Donovan, S.K. 2011. A review of the British Silurian cystoids. Geological Journal, 46:434-450. https://doi.org/10.1002/gj.1287 
Peach, B.N., Clough, C.T., Hinxman, L.W., Grant Wilson, J.S., Crampton, C.B., Maufe, H.B., and Bailey, E.B. 1910. The Geology of the Neighbourhood of Edinburgh, (Sheet 32, with part of 31), second edition. Memoirs of the Geological Society of Scotland.

Peach, B.N. and Horne, J. 1899. The Silurian Rocks of Britain, 1: Scotland. Memoirs of the Geological Survey of the United Kingdom.

Peel, J.S. 1973. A Silurian Gastropod Fauna from the Arisaig Group of Nova Scotia. Unpublished PhD thesis, University of Leicester.

Pitcher, B.L. 1939. The Upper Valentian gastropod fauna of Shropshire. Annals and Magazine of Natural History, 11(4):82-132. https://doi.org/10.1080/00222933908526975

Ramsköld, L. and Edgecombe, G.D. 1993. Silurian (Ludlow) acastid trilobites from Gotland and Scania, Sweden. Paläontologische Zeitschrift, 67:261-285. https://doi.org/10.1007/ BF02990280

Ramsköld, L. and Edgecombe, G.D. 1994. Revision of the Silurian encrinurine trilobite Wallacia Lamont 1978, with species from Gotland and Canada. Paläontologische Zeitschrift, 68(1/ 2):89-115. https://doi.org/10.1007/BF02989435

Ramsköld, L. and Werdelin, L. 1991. The phylogeny and evolution of some phacopid trilobites. Cladistics, 7:29-74. https://doi.org/10.1111/j.1096-0031.1991.tb00021.x

Reed, F.R.C. 1931. The Lower Palaeozoic trilobites of Girvan. Supplement 2. Monograph of the Palaeontographical Society, London:1-30 (Publ. No. 382, part of Volume 83).

Robertson, G. 1989. A palaeoenvironmental interpretation of the Silurian rocks of the Pentland Hills, near Edinburgh, Scotland. Transactions of the Royal Society of Edinburgh: Earth Sciences, 80:127-141. https://doi.org/10.1017/S0263593300014425

Salter, J.W. 1860. On new fossil Crustacea from the Silurian rocks. Annals and Magazine of Natural History, 3:153-162. https://doi.org/10.1080/00222936008697194

Salter, J.W. 1861. Notes on the Silurian fossils of the Pentland Hills. In Howell, H.H. and Geikie, A. (eds.), The Geology of the Neighbourhood of Edinburgh. Map 32 - Scotland. Memoirs of the Geological Survey of Great Britain and of the Museum of Practical Geology.

Shergold, J.H. 1967. A reappraisal of the North American species of the Siluro-Devonian trilobite genus Scotiella. Postilla, 112:1-20.

Slater, I.L. 1907. A monograph of British Conulariæ. Monograph of the Palaeontographical Society, London:1-40, pls 1-5 (Publ. No. 295, part of Volume 61).

Stewart, S.E., Anderson, L.I., and Clarkson, E.N.K. 2007. Miscellanea, p. 195-200. In Silurian fossils of the Pentland Hills. In Scotland Clarkson, E.N.K., Harper, D.A.T., Taylor, C.M., and Anderson, L.I. (eds.). Palaeontological Association Field Guides to Fossils: number 11. The Palaeontological Association, London.

Storey, A.J. 2012. Late Silurian Trilobite Palaeobiology and Biodiversity. Unpublished PhD thesis, University of Birmingham.

Strusz, D.L. 1980. The Encrinuridae and related trilobite families, with a description of Silurian species from Southeastern Australia. Palaeontographica Abteilung, A168:1-68, 6 pls, 16 textfigs, 6 tables.

Thompson, E.H. 1970. Morphology and taxonomy of Cyclonema Hall (Gastropoda), Upper Ordovician Cincinnatian Province. Bulletins of American Paleontology, 58(261):219-274, pls 31-35.

Trauschold, H. 1867. Einige Crinoideen und andere Thierreste des jungeren Bergkalks in Gouvernement Moskau. Bulletin de la Société Impériale des Naturalistes de Moscou, 4(3):147, pls 1-5.

Van Iten, H. 1992. Morphology and phylogenetic significance of the corners and midlines of the conularliid test. Palaeontology, 35(2):335-358.

Wagner, P.J. 2001. Gastropod phylogenetics: progress, problems and implications. Journal of Paleontology, 75:1128-1140. https://doi.org/10.1017/S0022336000017182

Whittington, H.B. 1950. British Trilobites of the Family Harpidae. Monograph of the Palaeontographical Society, London:1-55, pls 1-7 (Publ No 447, part of Volume 103). 


\section{APPENDIX}

Table summarizing the present authors' taxonomic decisions, based on the present article and published literature, against each name proposed by Lamont. The table also lists the species according to major taxonomic groups.

\begin{tabular}{|c|c|c|c|c|c|}
\hline Plate & Page & Group & Lamont's name & Revised name & Revised group \\
\hline $25(1-3)$ & 246 & \multirow{27}{*}{ Gastropoda } & Fingala galea & nomen dubium & ? Gastropoda \\
\hline $25(4)$ & 248 & & Pterotheca gath & Pterotheca gath & \\
\hline $25(5)$ & 246 & & $\begin{array}{l}\text { Bucaniopsis expansa } \\
\text { galaensis }\end{array}$ & nomen nudum & Gastropoda \\
\hline $25(6,7)$ & 247 & & Cymbularia johannis & nomen nudum & \\
\hline $25(8)$ & 247 & & Bellerophon kentigerni & Bellerophon kentigerni & $\begin{array}{l}\text { uncertain position: } \\
\text { Gastropoda or } \\
\text { Monoplacophora }\end{array}$ \\
\hline $\begin{array}{c}25(9) \\
26(10)\end{array}$ & $\begin{array}{l}252 \\
252\end{array}$ & & $\begin{array}{l}\text { Platyceras (Acroculia?) } \\
\text { antiquata }\end{array}$ & Platyceras (Acroculia?) antiquata & \multirow{22}{*}{ Gastropoda } \\
\hline $25(10)$ & 253 & & Hormotoma balmerino & nomen dubium & \\
\hline $26(1)$ & 247 & & Cyrtolites (Balsillia) limbus & Cyrtolites (Balsillia) limbus & \\
\hline $26(2)$ & 249 & & Phanerotrema tomkeieffi & Phanerotrema balteata & \\
\hline $26(3)$ & 251 & & Eckfordius scoticus & nomen dubium & \\
\hline $26(4)$ & 252 & & Gyronema cuthberti & Gyronema salteri & \\
\hline $26(5)$ & 248 & & Cockriggia trilineata & Cockriggia trilineata & \\
\hline $26(6)$ & 248 & & Euryzone? millsi & nomen nudum & \\
\hline $26(7,8)$ & 252 & & Gyronema? peerie & nomen nudum & \\
\hline $26(9)$ & 251 & & Annerlia crinolin & nomen nudum & \\
\hline $26(11)$ & 253 & & Hormotoma henshawi & Hormotoma henshawi & \\
\hline $26(12)$ & 253 & & Hormotoma ahania & Hormotoma ahania & \\
\hline $26(13)$ & 253 & & Chambersius zonatus & Hormotoma sp. & \\
\hline $26(14)$ & 254 & & Girvania jacobea & nomen nudum & \\
\hline $26(15)$ & 254 & & Oithonaconcha macphersoni & Loxonema sp. & \\
\hline $27(1,2)$ & 250 & & Polytropina splad & nomen nudum & \\
\hline $27(3,4)$ & 250 & & Oriostoma ocellus & nomen nudum & \\
\hline $27(5-9)$ & 251 & & Oriostoma polymetis & nomen dubium & \\
\hline $27(10,11)$ & 251 & & MacColla arcana & nomen dubium & \\
\hline $27(12,13)$ & 249 & & Euomphalopterus zigzag & Euomphalopterus cf. apedalensis & \\
\hline $27(14-16)$ & 249 & & Muiheada simulans & Platyschisma simulans & \\
\hline- & 265 & & Haswellia macrothalma & not figured by Lamont & \\
\hline $27(21)$ & - & \multirow{9}{*}{ Bivalvia } & Anadontopsis cf. salteri & Anodontopsis lucina? & \multirow{9}{*}{ Bivalvia } \\
\hline $28(1)$ & 255 & & Pitcairniellus rebel & Pitcairniellus rebel & \\
\hline $28(2)$ & 256 & & Ctenodonta cf. obesa & Ctenodonta cf. obesa & \\
\hline $28(3)$ & 256 & & Eopterinopecten alindaba & nomen dubium & \\
\hline $28(4)$ & 256 & & Tearlach trippi & Grammysia obliqua & \\
\hline $28(5)$ & 257 & & Cuneamya neilmunro & nomen dubium & \\
\hline $28(6)$ & 257 & & Orthonota dulcibella & Orthonota dulcibella & \\
\hline $28(7)$ & 258 & & Orthonota gentilis & Orthonota gentilis & \\
\hline $28(8)$ & 258 & & Orthonota cf. bulla & Orthonota cf. bulla & \\
\hline
\end{tabular}




\begin{tabular}{|c|c|c|c|c|c|}
\hline Plate & Page & Group & Lamont's name & Revised name & Revised group \\
\hline $27(22)$ & 260 & \multirow{10}{*}{ Cephalopoda } & Chantrakionoceras scoticum & Chantrakionoceras scoticum & \multirow{10}{*}{ Cephalopoda } \\
\hline $28(9)$ & 258 & & Scotokionoceras naxa & Gorbyoceras sp. & \\
\hline $28(10)$ & 259 & & $\begin{array}{l}\text { Orthoceras (Pictorthoceras) } \\
\text { humilis }\end{array}$ & nomen dubium & \\
\hline $29(1)$ & 261 & & Phragmocerina? worthyi & Phragmoceras ventricosum & \\
\hline $29(2)$ & 261 & & & nomen nudum & \\
\hline $29(3-5)$ & 261 & & Protophragmoceras erskinei & Protophragmoceras erskinei & \\
\hline $29(6)$ & 260 & & Gomphoceras monboddo & 'Gomphoceras' sp. & \\
\hline $29(7,8)$ & 260 & & Hexameroceras scoturum & Octameroceras scotorum & \\
\hline $29(9)$ & 260 & & Patieoceras patiei & 'Gomphoceras' sp. & \\
\hline $29(10)$ & 259 & & $\begin{array}{l}\text { Polygrammoceras } \\
\text { (Flettoceras) filibeg }\end{array}$ & Geisonoceras maclareni & \\
\hline $27(17,18)$ & 262 & \multirow{3}{*}{ Coelenterata } & $\begin{array}{l}\text { Metaconularia sowerbyi } \\
\text { galaensis }\end{array}$ & Conularia hastata & \multirow{3}{*}{ Cnidaria } \\
\hline $27(19)$ & 262 & & Conularia chevron & nomen dubium & \\
\hline $27(20)$ & 262 & & Crockettius aboriginis & Conularia hastata & \\
\hline $28(11,12)$ & 262 & Hyolitha & Hyolithes adamas & nomen dubium & Hyolitha \\
\hline $28(13-18)$ & 263 & $\begin{array}{l}\text { Echinoderma, } \\
\text { Machaeridia }\end{array}$ & Plumulites ruskini & $\begin{array}{l}\text { nomen dubium } \\
\text { Compacoleus? sp. } \\
\text { Plumulites lamonti }\end{array}$ & $\begin{array}{l}\text { Annelida, } \\
\text { Machaeridia }\end{array}$ \\
\hline $29(11)$ & 264 & \multirow{4}{*}{$\begin{array}{l}\text { Echinoderma, } \\
\text { Carpoidea }\end{array}$} & McCallienellus catherinae & nomen invalidum & \multirow{4}{*}{$\begin{array}{l}\text { Echinodermata, } \\
\text { Crinoidea }\end{array}$} \\
\hline $29(12)$ & 264 & & Learmontella epicyclica & nomen invalidum & \\
\hline $29(13)$ & 264 & & Vallasius disjectus & nomen invalidum & \\
\hline $29(14)$ & 264 & & Gabbatha hoplites & nomen invalidum & \\
\hline $25(11)$ & 268 & \multirow{14}{*}{ Trilobita } & Cuchulain lugi & Cuchulain lugi & \multirow{14}{*}{ Trilobita } \\
\hline $30(1-4)$ & 265 & & Proetus (Forbesia?) pitcairni & Proetus (Lacunoporaspis) sp. & \\
\hline $30(5)$ & 266 & & $\begin{array}{l}\text { Proetus (Scotoproetus) } \\
\text { fergali }\end{array}$ & Proetus (Lacunoporaspis) sp. & \\
\hline $30(6,7)$ & 267 & & $\begin{array}{l}\text { Cyphoproetus (Carlopsia) } \\
\text { glaudii }\end{array}$ & nomen nudum & \\
\hline $30(8-10)$ & 266 & & $\begin{array}{l}\text { Cyphoproetus } \\
\text { (Cornuproetus) dicuili }\end{array}$ & Proetus (Lacunoporaspis) sp. & \\
\hline $30(11)$ & 267 & & Cyphoproetus cf. punctillosus & Cyphoproetus comitilis & \\
\hline $30(12)$ & 267 & & $\begin{array}{l}\text { Cyphoproetus (Otademus) } \\
\text { alacer }\end{array}$ & Acernaspis sp. & \\
\hline $30(13)$ & 268 & & Praedechenella peeblesi & Proetus (Lacunoporaspis) sp. & \\
\hline $30(14-16)$ & 274 & & Youngia douglasii & Youngia douglasii & \\
\hline $30(17,18)$ & 275 & & Hemiarges hendersoni & Hemiarges hendersoni & \\
\hline $30(19,20)$ & 275 & & Bruxaspis dealgach & Anacaenaspis dealgach & \\
\hline $30(21)$ & 276 & & Dudleyaspis lothiana & Leonaspis lothiana & \\
\hline $31(1)$ & 269 & & Aytounella scotica & Aytounella scotica & \\
\hline $31(2)$ & 269 & & $\begin{array}{l}\text { Acernaspis (Eskaspis) } \\
\text { sufferta var. ? }\end{array}$ & Acernaspis (Eskaspis) sufferta & \\
\hline
\end{tabular}




\begin{tabular}{|c|c|c|c|c|c|}
\hline Plate & Page & Group & Lamont's name & Revised name & Revised group \\
\hline $31(3,4)$ & 269 & & Acernaspis (Eskaspis) phylax & Acernaspis phylax & \\
\hline $31(5)$ & 270 & & Calgachia calgach & Encrinurus expansus & \\
\hline $31(6)$ & 271 & & Paracalgachia henshawensis & Encrinurus pagei & \\
\hline $31(7)$ & 271 & & Wallacia expansa & Encrinurus pagei & \\
\hline $31(8)$ & 271 & & Aristobeggia bargainiensis & nomen dubium & \\
\hline $31(9)$ & 272 & & Leitchia knockgairdnerensis & Encrinurus hagshawensis & \\
\hline $31(10)$ & - & & Brycewylia mira & Encrinurus hagshawensis & \\
\hline $31(11,12)$ & 273 & Trilobita & $\begin{array}{l}\text { MacGuiganella } \\
\text { hagshawensis }\end{array}$ & Encrinurus hagshawensis & Trilobita \\
\hline $31(13,14)$ & 273 & & Curriella newlandensis & Curriella newlandensis & \\
\hline $31(15)$ & 274 & & Curriella (Saoria?) prisca & Encrinurus priscus & \\
\hline $31(16)$ & 272 & & Trippia penkillensis & Encrinurus mullochensis & \\
\hline- & 265 & & Scotoharpes domina & Scotoharpes domina & \\
\hline- & 270 & & Encrinurus (Frammia) pagei & not figured by Lamont & \\
\hline- & 274 & & Calymene carlops & Calymena frontosa & \\
\hline $31(17,18)$ & 277 & Ostracoda & Craspedobolbina rennieana & Craspedobolbina rennieana & Ostracoda \\
\hline $32(1)$ & 277 & $\begin{array}{l}\text { Chordata, } \\
\text { Agnatha }\end{array}$ & Mirmor andreae & Atractosella andreae & Cnidaria \\
\hline- & 279 & Tunicata & Taitia catena & Dictyocaris ramsayi & Algae \\
\hline
\end{tabular}

